Revista lus et Praxis, Año 21, № 2, 2015, pp. 441 - 480

ISSN 0717 - 2877

Universidad de Talca - Facultad de Ciencias Jurídicas y Sociales

La "función" cautelar del juez en el proceso laboral.

¿Consagración de una potestad cautelar genérica?

Francisco Alberto Ruay Sáez

Trabajo recibido el 25 de febrero y aprobado el 1 de julio de 2014

\title{
La "función" cautelar del juez en el proceso laboral. ¿Consagración de una potestad cautelar genérica?
}

Francisco Alberto Ruay Sáez*

\section{Introducción}

Nuestro legislador ha pretendido imbuir con un claro sesgo ideológico activista $^{1}$ todas las normas procesales laborales que se consagran en el Libro $\mathrm{V}$ del Código del Trabajo ${ }^{2}$, tal como ha ocurrido a propósito de la novedosa regulación procesal de otras materias ${ }^{3}$. Así, por ejemplo, los principios formativos de impulso procesal de oficio, buena fe y celeridad, entre otros, han pretendido trasladar a la judicatura laboral elementos compensatorios propios de la naturaleza de la relación laboral sustantiva (como podría ser la naturaleza alimentaria de los derechos en litigio), entregando al juez herramientas que le permitan Ilevar a cabo dicha tarea. En otras palabras, el Estado legislador al parecer pretende encomendar la realización de la justicia social y la redistribución de ingresos directamente al Estado Juez, para que éste, instrumentalizando el proceso como medio de realización de fines trascendentales, pueda llevar adelante la concretización dinámica de las metas políticas impuestas por el propio Estado (en este caso convendría Ilamarlo Gobierno).

Expresión de la intención anteriormente descrita la encontramos en textos normativos que pareciesen consagrar de manera atípica y abierta las potestades judiciales en sede laboral. Pero cuidado, antes de emprender tránsito por el camino propuesto es preciso que nos preguntemos, al menos, lo siguiente: ¿ es válido sostener que aquella modalidad de atribución potestativa tiene lugar en nuestro ordenamiento jurídico vigente?; ¿respeta dicha modalidad potestativa

\footnotetext{
* Ayudante ad honorem de la cátedra Derecho del Trabajo en el Departamento de Derecho del Trabajo y de la Seguridad Social, y de Criminología en el Departamento de Ciencias Penales en la Universidad de Chile, Santiago, Chile. Abogado. Licenciado en Ciencias Jurídicas y Sociales, Universidad de Chile. Correo electrónico: fruay@ug.uchile.cl; fruaysaez@gmail.com

1 Sobre el estado actual de la cuestión en Chile, respecto de la judicatura en general. consultar: GARCíA y Verdugo (2013).

2 Al respecto consultar: Palavecino (2012), pp. 59-68; Palomo y Matamala (2012), pp. 237-274.

3 Hunter (2011), pp. 73-101; Ruay (2013), pp. 53-82; Hunter (2007), pp. 205-229; Carretta (2014), pp. 481-495.
} 
la noción misma de proceso en un Estado democrático de Derecho?; y simultáneamente ¿cabe en el caso de los tribunales del trabajo afirmar su sujeción plena al principio de juridicidad?; ¿Cuál es el posible alcance de las normas así consagradas? Éstas serán algunas de las preguntas que intentaremos responder en el presente estudio.

La intención escondida por muchos tras un discurso activista del rol del juez en el proceso no representa un mero interés epistemológico revestido de bondad. Implícitamente, y de manera particular en el proceso laboral, se aboga por la configuración de un juez activista pro trabajador, desequilibrando de esta manera estructuralmente la posición de las partes en el proceso laboral. Sucede algo similar a lo que se señala a propósito del análisis de la voluntad legislativa tras la ley procesal laboral en Venezuela: "La ley procesal laboral amplía tanto las facultades inquisitorias del juez en la búsqueda de la verdad con el objeto principal de proteger el débil económico en la contratación de trabajo, que quizás incurriendo en un error conceptual en criterio de los procesalistas, se establece una especie de extensión del indubio pro operario, que abarca ya no solo la duda en la interpretación de una norma, sino la apreciación de los hechos o las pruebas" ${ }^{\prime 4}$. La interpretación de la ley sustantiva evidentemente tiene que estar guiada, por especialidad de materia; por el principio pro operario. El Derecho del Trabajo ha surgido y se ha desenvuelto como una rama del Derecho particularmente protectora, y es evidente que la realización de su espíritu ha de contener en cada regulación normativa existente y venidera dicha voluntad y atención particular, en beneficio de los trabajadores. Sin embargo, desde dicha conclusiva, a afirmar que sea también la ley procesal quien sistemáticamente oriente al tribunal a favorecer a una de las partes, más aún otorgando potestades oficiosas atípicas, existe una gran distancia. Con ello se barre con uno de los principios fundamentales del proceso, uno de sus presupuestos: la igualdad entre las partes y la igualdad ante la ley, y se deja a la noción de proceso vacía de contenido.

En el contexto descrito es de nuestro interés particular abordar el análisis de la norma contenida en el texto normativo del artículo 444 del Código del Trabajo, que regula la denominada "función cautelar" del juez laboral.

Para lograr nuestro objetivo separaremos el desarrollo de la argumentación en dos cuerpos centrales. En el primero analizaremos sucintamente la sujeción de los tribunales del trabajo al principio constitucional de juridicidad y su alcance. En una segunda parte nos adentraremos directamente al estudio de las medidas cautelares, analizando la consagración normativa pertinente y los desarrollos doctrinales que nos permitirán definir su ámbito de aplicación.

4 Bontes y Mirabal (2012). 


\section{La sujeción de los tribunales del trabajo al principio de juridicidad}

\subsection{El Poder Judicial y la Función jurisdiccional del Estado}

El Estado moderno ha monopolizado el uso de la fuerza, erradicado la autotutela como forma legítima de solución de conflictos intersubjetivos, y en su lugar ha institucionalizado al Proceso como medio idóneo de resolución. La labor concreta de solucionar dichos conflictos a través del Proceso se encarga principalmente al Poder Judicial, y de manera más precisa, a los jueces de la República que constituyen a su vez los Tribunales de Justicia.

En el presente apartado no nos referiremos de manera especial a la justicia privada o los llamados jueces arbitrales ${ }^{5}$, sino sólo a aquellos jueces que, como funcionarios públicos, son parte del Poder Judicial por disposición expresa de la ley, tanto en su faz orgánica, como en la funcional o procedimental.

El Poder Judicial ${ }^{6}$, tal como se concibe en nuestro Ordenamiento Jurídico, y en general en toda la tradición jurídica continental, es un órgano que forma parte del Estado. No nos enfrentamos a una organización autónoma del poder estatal surgida desde la sociedad civil para la propia resolución de sus conflictos intersubjetivos entre pares, sino que es el Estado, como persona jurídica de derecho público, quien pone a disposición de los particulares este órgano con la finalidad de que aquellos que tienen un conflicto intersubjetivo de interés encuentren la solución definitiva a su disenso, previa delegación de la resolución sustantiva del conflicto al propio Estado, representado en este caso en el Poder Judicial, y en concreto, en el juez de la causa que, para cumplir con la tarea encomendada, deberá fallar conforme a derecho, de manera imparcial, habiendo oído previamente las alegaciones de ambas partes. En este caso, al referirnos al juez, debemos comprender por tal "obviamente, al órgano del Estado que ha sido atribuido por la Constitución de la función jurisdiccional,

\footnotetext{
${ }_{5}^{5}$ Árbitro es el particular (no funcionario del Estado) a quien se encarga el rol de juzgador por particulares y que no tiene aptitud para ejecutar su laudo. En palabras de Alvarado Velloso "el arbitraje (o el arbitramiento) es un modo de heterocomposición de litigios que opera como resultado respecto de ellos y al cual se llega sólo si media, al menos, un principio de autocomposición de los propios interesados, por la cual aceptan plantear su litigio al árbitro (o al arbitrador) y, eventualmente, acatar su decisión". En: AlvaradoVelloso (2011), p. 322.

${ }^{6}$ El Constituyente decidió utilizar la denominación clásica sólo respecto de este órgano, no así en el caso del Legislativo y el Ejecutivo. Aquella consideración especial puede estar fundada en la especial exclusividad de la actividad judicial respecto del órgano en comento. En cambio, la función legislativa es ampliamente compartida por el Congreso y el Ejecutivo representado en la figura del Presidente de la República. En todo caso, de lo que no cabe duda es que con la nominación utilizada se vincula directamente el ejercicio de la función jurisdiccional con determinados órganos del Estado.
} 
esto es, decidir de modo independiente e imparcial contiendas entre partes, es decir, tribunales de justicia"7, tal como entiende el profesor Soto Kloss.

En palabras del profesor Alvarado Velloso, "la esencia de la actividad jurisdiccional, que la tipifica de modo inconfundible por ser irrepetible en el Derecho, es la sustitución que cumple la autoridad respecto del intelecto y de la volición de los particulares en conflicto" ${ }^{\prime 8}$.

Ahora bien, tal como afirma el mismo profesor Alvarado, "aunque a primera vista parezca que existe una perfecta correspondencia entre cada función y cada Poder, ella no se presenta en la vida jurídica: salvo el caso del Poder Ejecutivo, que no puede ni debe efectuar tarea jurisdiccional, cada una de las funciones [...] [legislativa, administrativa y jurisdiccional] es cumplida (aunque a distintos niveles) de modo concurrente por cada uno de los poderes que actúan en el Estado organizado constitucionalmente ${ }^{\prime \prime}$. Por lo mismo, hay que aclarar que cuando hacemos referencia al Poder Judicial nos referimos preferentemente "al conjunto de jueces en su estructura orgánica, al que se encuentra confiado primeramente (aunque no en forma exclusiva) el ejercicio de la función jurisdiccional"10, considerando que hay lugar para situaciones excepcionalísimas de Tribunales que no son parte del Poder Judicial ${ }^{11}$, y aun así se puede afirmar que por definición ejercen una función jurisdiccional; y que, además, hay casos también excepcionalísimos en que la función jurisdiccional es desarrollada por el Poder Legislativo ${ }^{12}$.

De acuerdo a la doctrina nacional, si bien no se hace una mención expresa del principio de juridicidad en la Constitución, es posible sostener que éste se desprende de los preceptos contenidos en su capítulo I, que regula las bases de la institucionalidad, y específicamente en los artículos $6^{\circ}$ y $7^{013}$.

\footnotetext{
7 Soto Kloss (1996), p. 39.

${ }^{8}$ Alvarado Velloso (2011), p. 126.

9 Alvarado Velloso (2011), p. 122.

10 Aldunate (1995), p. 20.

11 Aldunate, en un pie de página señala que "Todos los tribunales ejercen jurisdicción (esto es, la facultad de desarrollar y satisfacer la función jurisdiccional) art. 73 i. I (actualmente art. 76 i. I]. Y en principio, sólo ellos [...] Pero hay tribunales que no forman parte del Poder Judicial: art. 73. [actualmente art. 76]. La misma Constitución menciona al menos tres: TC, TCE Y tribunales electorales regionales". Aldunate (1995), p. 20.

${ }^{12}$ Arts. $52 \mathrm{~N}^{\circ} 2$ y $53 \mathrm{~N}^{\circ} 1$ de la Constitución de la República, sobre el conocimiento de las acusaciones a las que allí se hace referencia; y art. $53 \mathrm{~N}^{\circ} 3$ de la Constitución, sobre contiendas de competencia. En: Aldunate (1995), p. 19. En opinión de Alvarado Velloso procedería sólo en el caso del juicio político. Alvarado Velloso (2011), p. 122.

${ }^{13}$ En lo pertinente indica lo siguiente: "Artículo 60: Los órganos del Estado deben someter su acción a la Constitución y a las normas dictadas conforme a ella, y garantizar el orden institucional de la República.
} 
El profesor Eduardo Soto Kloss ha sido quien ha estudiado de manera más acabada los alcances y la delimitación del principio de juridicidad en nuestro ordenamiento jurídico. Ha señalado, de manera concisa, que dicho principio consistiría en "la sujeción integral a Derecho de los órganos del Estado tanto en su ser como en su obrar"14.

El profesor José Luis Cea Egaña a su vez, comprende que "en virtud de tal principio se entiende que la atribución de cualquier competencia debe ser hecha de manera previa y expresa, limitada y otorgada con nitidez, nada más que por la Constitución o la ley"15.

El principio de juridicidad se encarga de resguardar la sujeción de absolutamente todos los órganos del Estado al imperio del Derecho, y de esta forma, asegura de manera manifiesta la existencia de un Estado Constitucional de Derecho. Por lo mismo, tiene un alcance más amplio que su versión pretérita conocida tradicionalmente como "principio de legalidad", en donde la sujeción podía entenderse vinculada solamente a la ley formal dictada por el Poder Legislativo. Esa concepción se veía atravesada por un gran problema, que es posible desprender de la misma conceptualización del principio de legalidad: si es el Poder Legislativo quien configura las potestades de los órganos estatales, podría eventualmente sostenerse que este poder no estuviera sujeto en su actuación a mayores limitaciones, pues él mismo creaba la ley atributiva y realizaba en concreto el espíritu de la Constitución.

En relación con esta última idea, el profesor Jorge Reyes señala que "[e]l vocablo legalidad conduce a la ley [...] y en verdad la sumisión del Estado no es solo a la ley, sino al Derecho que comprende diferentes órdenes jurídicos, involucra supremacía normativa y especialmente constitucional $[\ldots]^{\prime \prime 16}$.

Los preceptos de esta Constitución obligan tanto a los titulares o integrantes de dichos órganos como a toda persona, institución o grupo.

La infracción de esta norma generará las responsabilidades y sanciones que determine la ley.

Artículo $7^{\circ}$ : Los órganos del Estado actúan válidamente previa investidura regular de sus integrantes, dentro de su competencia y en la forma que prescriba la ley.

Ninguna magistratura, ninguna persona ni grupo de personas pueden atribuirse, ni aun a pretexto de circunstancias extraordinarias, otra autoridad o derechos que los que expresamente se les hayan conferido en virtud de la Constitución o las leyes.

Todo acto en contravención a este artículo es nulo y originará las responsabilidades y sanciones que la ley señale".

14 SOto Kloss (1996), p. 24.

15 Cea Egaña (2008), p. 252.

16 ReYes (1998), pp. 85-102, p. 85 
En consecuencia, y de manera evidente, no sólo el ejercicio de la función administrativa desarrollada por parte del Poder Judicial ${ }^{17}$ queda cubierta por el principio de juridicidad, como podría llegar a pensarse si se relaciona este principio netamente con la función ejecutiva del Estado, sino que lógicamente este órgano también se encuentra sujeto al principio de juridicidad en el ejercicio de la función jurisdiccional.

La función jurisdiccional del Estado, a su vez, se satisface y materializa en la heterocomposición pacífica de los conflictos intersubjetivos de intereses por parte de un juez o tribunal imparcial ${ }^{18}$, a través de un proceso judicial, lo que nos permite concluir que concretamente el juez, en el desenvolvimiento dialéctico del Proceso, deberá sujetar su actuación al principio de juridicidad, en tanto órgano del Estado.

Es posible deducir de manera lógica la sujeción de los Tribunales de Justicia establecidos en la ley, al principio de juridicidad, desde la verificación conceptual de que éstos en tanto constituyen el Poder Judicial son órganos del Estado $^{19}$. Luego, al analizar la descripción clásica del principio ${ }^{20}$ la aplicación del silogismo es evidente.

Para mayor abundancia, diversos autores no han dudado en referirse de manera explícita al Poder Judicial y los Tribunales de Justicia, a propósito de la descripción de su configuración y posición orgánica. Así, por ejemplo Jorge Reyes al referirse a los órganos estatales sometidos al principio de juridicidad señala que "si es el Estado quien se encuentra obligado por este principio, quiere decir que todos sus órganos, sin excepción alguna, también lo están. Es decir, si el Gobierno se halla en este deber, también lo está [...] el Poder Judicial $[\ldots]^{\prime 21}$. En el mismo sentido el profesor Hugo Caldera señala que

\footnotetext{
17 Por ejemplo, en la designación del personal del propio tribunal, o en el desenvolvimiento de la superintendencia económica de la Corte Suprema, como manifestaciones de algún grado de autonomía o independencia del Poder Judicial. Sin embargo, tal como señala Aldunate: "la idea de esta autonomía es crear un espacio de regulación y gestión excluido de los demás poderes, para permitir a la propia estructura judicial configurar sus "aspectos domésticos". No existe, sin embargo, una reserva frente al legislador: la ley siempre podrá entrar a regular estos aspectos" Aldunate (1995), p. 21.

18 Por disposición expresa de la Constitución en su artículo 76 se señala que: "[l]a facultad de conocer de las causas civiles y criminales, de resolverlas y de hacer ejecutar lo juzgado, pertenece exclusivamente a los tribunales establecidos por la ley".

19 "No cabe duda alguna que la función jurisdiccional, concretada orgánicamente en los tribunales de justicia, está comprendida dentro de la actividad que desarrollan los órganos del Estado, puesto que la disposición indicada [art. $6^{\circ}$ Constitución] se refiere genérica y globalmente a todos los órganos públicos". Caldera (1982), p. 30.

20 "La sujeción integral a Derecho de los órganos del Estado tanto en su ser como en su obrar" Soto KLoss (1996), p. 24.

${ }^{21}$ Reyes (2000), p. 149. En otro lugar señala categóricamente que el artículo $6^{\circ}$ de la Constitución "hace aplicable el principio a las funciones y acciones. Ni la ley, ni la sentencia, ni el decreto, ni el
} 
"Sería un grave error circunscribir los efectos de la juridicidad al ámbito de la administración del Estado, en atención a que dicho principio también obliga a los tribunales de justicia. A título de ejemplo indicamos que el ejercicio de la función jurisdiccional también está sujeto al citado principio [...]"22, y el profesor Soto Kloss por su parte afirma que "el juez [...] también debe someter su acción a la Constitución, y a las normas dictadas conforme a ella y, por lo tanto rige a su respecto igualmente en plenitud e integralidad el principio de juridicidad"23.Por su parte, los profesores Jorge Bermúdez ${ }^{24}$ y Gustavo Fiamma ${ }^{25}$ también reconocen explícitamente la aplicación del principio de juridicidad respecto de los Tribunales de Justicia.

\subsection{La función jurisdiccional del Estado como una actividad reglada y vinculada; desde el principio de juridicidad y el garantismo procesal}

La función jurisdiccional desarrollada por el Estado consiste fundamentalmente en la resolución de conflictos intersubjetivos, previo desarrollo de un Proceso. Por lo tanto, las potestades otorgadas al Tribunal respectivo, en la dimensión relevante para nuestro análisis ${ }^{26}$ tienen como finalidad que dicho órgano guíe el desarrollo dialéctico del Proceso. En otras palabras, es posible afirmar que el Proceso es el medio por el cual los órganos del Estado llevan a cabo la función jurisdiccional, y por tanto, es en el desarrollo del Proceso mismo que el órgano en cuestión se encuentra sometido al principio de juridicidad.

La dimensión normativa relevante en nuestro análisis se encuentra en la ley procesal. Será ésta la encargada de definir las atribuciones del Tribunal para el desarrollo correcto del Proceso. Esto considera las normas procedimentales y también las orgánicas, vinculando al órgano en cuestión tanto en su finalidad como en su constitución y organización. Esto implica, indirectamente, que el Tribunal correspondiente en la resolución final del caso también se encuentra sujeto al principio de juridicidad. En el ejercicio hermenéutico que lo llevarán acoger o rechazar la pretensión alegada en juicio, mediante una argumentación jurídica racional contenida en la sentencia, está desarrollando su labor, y ejerciendo facultades, en un momento del desarrollo dinámico y continuo

acto de la toma de razón o de representación ni cualquier otro acto del Estado quedan al margen del principio". En: REYES (1998), pp. 85-102, p. 87.

22 Caldera (2001), p. 87.

23 SOTO KLOSS (1996), p. 348.

24 Bermudez (2008), p. 273.

${ }^{25}$ Fiamma (1991), p. 92.

${ }^{26}$ Un análisis de otro tipo podría realizarse a propósito de las facultades económicas, disciplinarias, y en general, de administración interna, con la que cuentan algunos tribunales de justicia. 
de la función jurisdiccional. Ahora, la particularidad en este caso, es que un aspecto esencial de la función jurisdiccional es que ésta se encuentra orientada a la mantención del orden social, sin que se pierda un grado razonable de previsibilidad de las actuaciones del Estado, con la finalidad de incrementar y hacer posible, en último término, el ejercicio de la libertad individual. La cosa juzgada, el principio de legalidad, y la reserva legal procesal ${ }^{27}$, en concreto, se encargan de otorgar la estabilidad y certeza jurídica requeridas; con la resolución que constituye sentencia de término del respectivo juicio se da fin al conflicto intersubjetivo que dio origen al proceso y mediante este acto estatal de clausura se extingue también el ejercicio de esta función ${ }^{28}$.

En este punto es preciso aclarar que no es baladí la posición ideológica que se tenga frente al rol de función jurisdiccional, en abstracto, como función del Estado. Por nuestra parte, comprendemos los fines del Proceso desde la doctrina del Garantismo procesal. Desde esa posición es posible sostener que la ley otorga potestades finalizadas en un cierto sentido; no queda al arbitrio de cada uno de quienes ejerzan la jurisdicción decidir cuál es la finalidad de las potestades que le han sido atribuidas, por ejemplo, obviando disposiciones legales para alcanzar la captura mística de la polémica "verdad material", o "verdad en la medida de lo posible".

La sujeción de la función jurisdiccional al principio de juridicidad es plenamente coherente con la concepción garantista del Proceso. En razón de aquello, sostenemos que es posible un acercamiento a dicho fenómeno desde ambos fundamentos teóricos, de manera simultánea y comprehensiva. La consagración del principio de juridicidad en nuestra Constitución de contenido eminentemente liberal permite fundar una comprensión del Proceso coherente con el Garantismo Procesal, a la vez que esta última noción otorga herramientas para la correcta comprensión de las potestades atribuidas en particular al órgano que ejerce la función jurisdiccional.

\subsection{Los Juzgados de Letras del Trabajo sujetos al principio de juridicidad}

Recordemos brevemente que tal como se han interpretado los textos normativos de los artículos $6^{\circ}$ y $7^{\circ}$ de la Constitución, para que pueda considerarse válida la actuación de cualquier órgano del Estado es necesaria siempre la

\footnotetext{
27 "Toda sentencia de un órgano que ejerza jurisdicción debe fundarse en un proceso previo legalmente tramitado. Corresponderá al legislador establecer siempre las garantías de un procedimiento y una investigación racionales y justos". Art. 19 № 3 inc. $5^{\circ}$ de la Constitución.

${ }^{28}$ Cabe señalar que también está facultado, en el ejercicio de la jurisdicción, para hacer ejecutar lo resuelto coactivamente. Este elemento diferencia el ejercicio público de la función jurisdiccional con el árbitro como juzgador privado, y es manifestación de la sustitución por parte de la autoridad, tanto de la violencia institucionalizada, como del elemento volitivo de los particulares que se encuentran en litigio.
} 
habilitación legal previa y expresa. Por tanto, queda de entrada absolutamente descartada la posibilidad de que el órgano respectivo, en nuestro caso el judicial, pueda autoatribuirse potestades ${ }^{29}$, y también se excluye manifiestamente la posibilidad de interpretar la norma procesal potestativa en un sentido tal que diese cabida a la teoría de las potestades implícitas, ya que la Constitución señala de manera literal que la atribución correspondiente ha de realizarse siempre de manera explícita.

Hasta aquí hemos hablado de quienes ejercen la función jurisdiccional del Estado en general, sin embargo todo lo que hemos señalado es plenamente aplicable respecto de cualquier órgano particular que ejerza dicha función; en nuestro caso particular lo relevante es que es plenamente aplicable a los Juzgados de Letras del Trabajo.

Desde un punto de vista orgánico, los Juzgados de Letras del Trabajo son parte del Poder Judicial, y constituyen un tribunal de carácter especial. Así lo señala el artículo $5^{\circ}$ del Código Orgánico de Tribunales ${ }^{30}$ y el artículo 417 del Código del Trabajo ${ }^{31}$. Este último consagra en su artículo 415 la dimensión organizacional de los Juzgados, la competencia territorial de estos tribunales y los jueces que integran cada uno de aquellos.

Podría pensarse que en virtud de la supuesta autonomía del derecho procesal laboral lo que hemos señalado previamente no es aplicable en el caso de que quien ejerce la función jurisdiccional sea un juez laboral. Sin embargo, esa supuesta autonomía no extiende su alcance al punto de generar paralelamente una nueva noción de Proceso que la haga posible; en otras palabras, la autonomía no implica dislocación funcional en este caso. Sin duda el procedimiento que deberá aplicar el juez laboral, y al que se atienen las partes en este caso, es diverso a otros (Civil, Penal o de Familia, por ejemplo) por la especial materia que se lleva a estrados, pero aquello no permite afirmar la absoluta autonomía del Proceso laboral como rama independiente y dislocada de la noción misma de Proceso. Lógicamente, las normas sobre competencia absoluta en relación a la materia, contenidas en los artículos 420 y 485, no permiten sostener el carácter autónomo de la labor realizada por el juez laboral. En todo caso, lo esencial y que aparece de manifiesto es que él siempre estará desarrollando

\footnotetext{
29 Aunque en realidad parece una paradoja: si se permite un ejercicio arbitrario del poder ya no estamos en presencia de su ejercicio legítimo, y por tanto no hay potestad, sino un mero acto de violencia ilegítima.

30 "Forman parte del Poder Judicial, como tribunales especiales [...] Los Juzgados del Trabajo [...]" Artículo $5^{\circ}$ inciso tercero del Código Orgánico de Tribunales.

31 "Los juzgados a que se refieren los artículos anteriores son tribunales especiales integrantes del Poder Judicial [...]" Artículo 417 Código del Trabajo.
} 
sólo la función jurisdiccional del Estado, y aquello ha de realizarlo siempre respetando las normas de un debido proceso garantista.

El Proceso se materializa en un procedimiento tipificado particular diseñado en respuesta a las necesidades y requerimientos de cada área sustantiva del Derecho. Sin embargo, aquello no implica en ningún caso que cada procedimiento pueda ubicarse conceptualmente por sobre las premisas que hacen posible la existencia lógica de un Proceso. O sea, si bien pueden existir procedimientos determinados por las respectivas materias que se traten en los litigios (bien por razones de conocimiento o experticia de los jueces en determinadas materias sustantivas, o por simple economía procesal), aquello no puede implicar en ningún caso contrariar la noción misma de Proceso, que supone a dos partes iguales puestas en contradicción dialéctica frente a un tercero que actúa de manera imparcial.

La Constitución, a su vez, no realiza ninguna distinción que permita señalar que el juez del Trabajo no se encuentra sujeto al principio de juridicidad, pues éste vincula a "todo órgano" del Estado. De hecho, el propio texto legal al que hemos hecho referencia anteriormente, al ubicar a los Juzgados del Trabajo en el Poder Judicial, no deja lugar a discusión alguna sobre su sujeción al principio de juridicidad. Podría discutirse en qué casos ejerce jurisdicción, si es posible que realice alguna función administrativa, o inclusive, si tienen facultades legislativas con alcance general, pero inclusive así, en todos estos casos la discusión siempre partiría condicionada por el principio de juridicidad a que se encuentra sujeto en tanto órgano del Estado.

El juez laboral, por lo tanto, actúa en representación del Estado en el ejercicio de la función jurisdiccional de éste, y su finalidad en ese sentido es fundamentalmente resolver los conflictos intersubjetivos entre determinados agentes a través de un proceso judicial, que como tal, debe ceñirse a los presupuestos esenciales de su consagración constitucional, y además, de manera coherente, al contenido doctrinario que brinda el garantismo procesal.

El razonamiento lógico es el siguiente: el Juez Laboral ha sido investido regularmente por el Estado, para la satisfacción y cumplimiento precisamente de una función estatal, cual es la jurisdiccional. Esa función la ha de cumplir a través del Proceso como método idóneo de solución de conflictos. En dicha labor, en tanto órgano del Estado, se encuentra sujeto al principio de juridicidad, en todas las dimensiones que comprende su tarea, y este principio a su vez ordena resguardar el respeto del debido proceso en el ejercicio de las potestades específicas que se le han conferido. Sólo luego de dilucidar cuál es el rol del juez en nuestro orden constitucional e institucional, en tanto agente público encargado de la función jurisdiccional del Estado, cabe asignar y reconocer para algunos de quienes está encargada la misma función un grado de especialidad por materia. En concreto, será el ámbito de competencia que se reconoce al 
magistrado lo que determinará las especiales materias que se asignen para su conocimiento. En el caso del juez laboral, es la propia ley la que encarga un conocimiento especial definido por la materia, pero señalando expresamente que el juez de letras respectivo, y el Juzgado, son parte del Poder Judicial. Además, sólo luego de aquello, la ley establece como forma de materialización de la función jurisdiccional que cumplirá (Proceso), una serie de reglas funcionales, reconocibles como procedimientos de carácter laboral; procedimiento de Aplicación General, Procedimiento de Tutela, Procedimiento Monitorio, por ejemplo. Es ese el orden lógico que ha de seguir nuestro análisis, y que permite ubicar al juez concreto, y el ejercicio del poder que se le ha conferido, como una manifestación particular del poder del Estado.

El juez laboral, en tanto agente del Estado, se encuentra sujeto al principio de juridicidad, y en ese sentido a él también se le prohíbe categóricamente la autoatribución de potestades, o la intervención activa en los aspectos materiales del Proceso.

\section{Las medidas cautelares del artículo 444 del Código del Trabajo}

Ya hemos expuesto en la sección previa el alcance vinculante general del Principio de Juridicidad respecto de los Tribunales de Justicia, y en particular, respecto de los jueces que ejercen la función jurisdiccional del Estado en materia laboral. A continuación analizaremos de manera particular la norma de atribución potestativa contenida en el artículo 444 del Código de la materia, avocándonos directamente sobre la supuesta "función cautelar del juez", y los eventuales alcances de ésta.

El artículo 444 en su inciso $1^{\circ}$ señala ${ }^{32}$ : "En el ejercicio de su función cautelar, el juez decretará todas las medidas que estime necesarias para asegurar el resultado de la acción, así como para la protección de un derecho o la identificación de los obligados y la singularización de su patrimonio", consagrando así legalmente la procedencia de medidas cautelares en el Proceso laboral.

La norma en cuestión es portadora del espíritu oficioso e inquisitivo que ensalza todo nuestro Proceso laboral desde su última reforma ${ }^{33}$, y otorga, en principio, un papel protagónico al juez, ahora en especial tratándose de la dictación de medidas cautelares. A este respecto, la cuestión trascendental gira en torno a la posibilidad de que desde el precepto se desprenda una supuesta

\footnotetext{
32 Si bien la totalidad del artículo 444 del Código del Trabajo se encarga de regular las medidas cautelares (prejudiciales y precautorias), creo que por ahora es este extracto del texto normativo que nutre con mayor consistencia las posibilidades de nuestra discusión. Esto obviamente no significa que obviemos el resto del precepto, sino que por el contrario; a medida que vayamos avanzando en el análisis iremos recurriendo a éstos en tanto sean pertinentes.

33 Lanata (2010), p. 70 y también en: Academia Judicial (2008).
} 
potestad cautelar genérica. Obviamente, si el juez tuviese una potestad de este tipo podría dictar medidas cautelares innominadas y atípicas, no sólo en el caso de ser solicitadas por las partes, sino también las que él pudiese estimar pertinente decretar de oficio.

Sin lugar a dudas es evidentemente distinto consagrar una función, así en general, a tipificar una potestad. En el caso de la noción de función se pretende asignar o describir la realización de determinada finalidad, adoptando dicha enunciación un carácter netamente descriptivo de un ser que ya es, por decirlo de alguna manera. La función no describe por sí misma las tareas encomendadas, ni las facultades, potestades o autorizaciones con las que contará determinado agente para la realización misma de la función. En ese sentido, es posible afirmar que la función es una consagración ideal genérica de un determinado ser, en tanto descripción abstracta del ámbito de acción, pero en ningún caso la expresión función ha de contener autorizaciones expresas ni tácitas para desarrollar la misma. En otras palabras, una cosa es decir que determinado agente cumplirá determinada función, y otra muy distinta es qué comprendemos por la realización efectiva de dicha función, y aún más lejos, el "cómo" se llevará a cabo la función en cuestión. Sólo es este último ámbito el que se puede asociar a la consagración de potestades, que tal como señalamos precedentemente, se encuentra encomendado de manera exclusiva al legislador, conforme a nuestro orden democrático.

A pesar de todo lo anterior, aún es posible sostener por algunos que la consagración de la función propiamente tal acarrearía de manera lógica, pero implícita, la consagración de una potestad cautelar genérica. Con esto se dejaría atrás la rígida y estática legalidad, posicionando coherentemente al juez en su posición de actor principal en el Proceso conforme al principio de impulso procesal de oficio.

Para acercarnos a la discusión planteada nos valdremos de la aclaración hecha por Rafael Ortiz-Ortiz realizada a propósito del Ordenamiento procesal civil venezolano, y en particular sobre los sistemas cautelares que es posible encontrar en los diferentes ordenamientos. Sería posible distinguir que la cautela opera bajo:

“a) Sistema Cautelar General: mediante un poder de tutela genérico que faculta al juez para dictar, cada vez que se produzca un peligro de daño jurídico derivado del retardo en el pronunciamiento de la providencia definitiva, las medidas cautelares que estime más aptas para obviarlo (poder cautelar genérico propiamente dicho, el cual se realiza a través de medidas innominadas o atípicas);

b) Sistema Cautelar Taxativo: mediante un poder de tutela restringido a las medidas cautelares que se han previsto específica y taxativamente en la ley, determinándose en cada caso sus condiciones de procedencia (el poder cautelar taxativo se cumple a través de medidas nominadas o típicas); 
c) Sistema Cautelar Mixto: mediante un poder de tutela limitado a ciertos casos a las medidas de carácter específico reguladas en la ley (medidas nominadas o típicas) y genérico, que autoriza al juez para decretar las que considere más eficaces, al fin que se pretende alcanzar"34.

Así, dependiendo de la interpretación que hagamos de la norma que se desprende del artículo 444 del Código del Trabajo podremos afirmar que nos encontramos en presencia de uno u otro sistema. Por nuestra parte, creemos que nos encontramos en un sistema mixto, lo que obviamente acarrea una serie de interrogantes a propósito de la juridicidad de la consagración de un ámbito abierto de realización potestativa del juez en el proceso laboral. La norma se encuentra vigente, y por tanto más allá de que nuestra interpretación nos guía a afirmar que la consagración de la potestad en cuestión no respeta el principio de juridicidad, es preciso que evaluemos propuestas hermenéuticas que nos permitan acceder coherentemente al texto normativo.

Si bien es complejo definir de manera acabada el concepto de "medidas cautelares", entre otras cosas por las constantes imprecisiones lingüísticas en que la propia doctrina se ha sumergido, al enunciarlas como "función cautelar", "medidas precautorias", "proceso cautelar", u otras nominaciones a las que no haremos referencia, creemos que la expresión "petición cautelar", utilizada por el profesor Alvarado Velloso abarca de mejor manera los diversos elementos que constituyen a esta institución ${ }^{35}$, y por ello, si bien utilizaremos la terminología comúnmente utilizada en la doctrina nacional y comparada, siempre tendremos en cuenta a la petición cautelar como eje paradigmático de análisis.

Al iniciar el análisis del precepto que regula las medidas cautelares en la legislación laboral, el primer elemento extravagante a que nos enfrentamos es la consagración expresa de una denominada "función cautelar" del juez laboral, tal como ya nos adentramos a analizar. Si hemos de dotar de algún contenido a dicha función nos es preciso señalar que consiste en primer lugar, comprendiendo de manera tradicional el contenido de la cautela en cuestión, en el aseguramiento del resultado del juicio para la parte demandante. En este ámbito se nos muestra que la medida cautelar que adoptará el juez, y la función cautelar del juez, de manera abstracta, tienen como finalidad última el aseguramiento o resguardo

\footnotetext{
${ }^{34}$ Ortiz (s/f), pp. 27-28.

35 Señala el profesor que: " [...]corresponde llamarlas peticiones cautelares toda vez que: a) la palabra petición (y no medida) alude a una de las cinco instancias ya conocidas, de carácter primario, con contenido pretensional y que no requiere bilateralidad previa. Creo que así se advierte de inmediato su naturaleza jurídica y se comprende mejor el fenómeno que aquí se describe; y b) la voz cautelar da clara idea del contenido de este tipo de pretensión, pues proviene de cauto y tal adjetivo muestra al litigante que intenta asegurar el resultado final de un litigio para el supuesto de obtener sentencia favorable a la pretensión demandada. Consecuente con ello, el objeto de la petición será siempre obtener un procedimiento (que es lo que existe en todo lo cautelar)". Alvarado (2011), p. 772.
} 
de la eficacia de los resultados de un proceso. En ese sentido, las medidas cautelares, desde una óptica clásica, tienen como finalidad última hacerse cargo de los problemas temporales consustanciales al propio desarrollo racional de un Proceso. En otras palabras, se buscará satisfacer idóneamente lo requerido por los particulares al acudir a la solución heterocompositiva del Tribunal, y en el fondo, del Estado, que no es ni más ni menos que la petición originaria pueda ser satisfecha de manera íntegra y equivalente a lo peticionado en su origen dialéctico al momento de la ejecución de lo resuelto. En palabras de Rangel Robles, y desde lo expuesto por el maestro Calamandrei, "lo que justifica las providencias cautelares, es pues, la existencia de un peligro de daño jurídico derivado del retardo de la providencia jurisdiccional definitiva" ${ }^{\prime 36}$.

Por su parte, el profesor Andrés Bordalí indica que "el objetivo que busca el proceso cautelar es permitir que la sentencia que dicará el juez referida a la tutela de un determinado derecho subjetivo o interés legítimo de una persona, pueda cumplirse en sus propios términos y no se haga así ilusoria, producto de sucesos que hayan acaecido durante el normal iter del proceso [...] y cuando digo en sus propios términos expreso la idea de que el acreedor quiere eso que demanda, y no un sustituto ${ }^{\prime 37}$. Es particularmente relevante esta apreciación que compartimos ${ }^{38}$ pues, trasladando el fundamento al Derecho del Trabajo, tendremos que la mayoría de los casos Ilevados a estrados contienen peticiones patrimoniales, y que el propio carácter fungible del dinero con que eventualmente ha de solucionarse la obligación incumplida permite justificar una interpretación restrictiva de la denominada "función cautelar" del juez, toda vez que bastarían resguardos de tipo patrimoniales para cautelar el futuro cumplimiento de lo pretendido en juicio. Eso sí, habrá que hacer la salvaguarda respecto de las "medidas reparatorias" que serían decretables en procedimiento de tutela de derechos fundamentales del trabajador, pues ahí habría que entrar a delimitar los contenidos posibles de la sentencia judicial de tutela, su vinculación con lo peticionado, y el principio de congruencia, además de la potestad judicial legal, ejercida de oficio o a petición de parte, para hacer cesar la vulneración desde la primera presentación del denunciante. Todas éstas, cuestiones que merecen un estudio particular que escapa a las pretensiones de la presente investigación, pero que no dudaremos en abordar en otro espacio, a futuro.

Es a propósito de una concepción activista del juez que las tradicionales medidas cautelares han ampliado su horizonte de intervención. Aquello, junto

36 RenGel (1989), p. 87.

37 Bordalí (2001), p. 53.

${ }^{38}$ Salvo la designación de "proceso" a lo cautelar, puesto que tal denominación permitiría aseverar que es posible pensar lo cautelar en forma diversa del sentido precautorio clásico, como independiente de un proceso principal. 
a la comprensión de las mismas en el derecho internacional de los derechos humanos, que suscitan una preocupación inmediata y urgente, ya no en la caución de un eventual resultado litigioso, sino en la protección inmediata de un derecho que comprenda dicha calidad. Así declaraba por ejemplo el ex presidente de la Corte Interamericana de Derechos Humanos Antonio Augusto Cançado que "[e] $\mathrm{n}$ el derecho internacional de los derechos humanos, las medidas provisionales van más allá en materia de protección, revelando un alcance sin precedentes: en el presente dominio, tales medidas, además de su carácter especialmente preventivo, protegen efectivamente derechos fundamentales, en la medida en que buscan evitar daños irreparables a la persona humana como sujeto del derecho internacional de los derechos humanos" ${ }^{\prime 39}$. Luego, es el carácter de víctima de vulneración de derechos fundamentales, y su superior consideración axiológica y normativa, además de la sede litigiosa supraestatal, los elementos particularísimos que conforman el fundamento sustancial de la ampliación de alcance de las tradicionales medidas cautelares en sede internacional.

El demandante buscará evidentemente que se le satisfaga lo más pronto posible, no sólo en el proceso laboral, sino en cualquier litigio, sin importar la materia, pero como el ejercicio racional de la jurisdicción supone un desarrollo en el tiempo existirán consustancialmente riesgos de disminución patrimonial, desvalorización, pérdidas por caso fortuito u otros similares. La función del juez consistirá en evitar que esos riesgos lleguen a concretarse, y el cómo será idealmente definido por la ley, en respeto del principio de juridicidad consagrado constitucionalmente. Tal como escribe Ovalle Favela, en referencia a lo sostenido por el maestro Chiovenda, "como la actividad del Estado, para operar la actuación de la ley (en ejercicio de la función jurisdiccional y a través del proceso) requiere tiempo y costos, se debe impedir que aquel que se haya encontrado en la necesidad de servirse del proceso para obtener razón reciba daño por el tiempo y costos requeridos: "la necesidad de servirse del proceso para obtener razón -afirmaba el procesalista italiano- no debe tornarse en un daño para quien tiene la razón ${ }^{40 \prime \prime}$.

En palabras de Plascencia Cruz "Toda medida cautelar está dirigida a asegurar el cumplimiento de la decisión definitiva en un proceso ya iniciado o por iniciarse [...] lo que se protege mediante las medidas cautelares es la ejecutividad y eficacia de la decisión futura, siempre que por el transcurso del tiempo en la dilucidación del conflicto, se haga ilusorio el pronunciamiento final"41.

\footnotetext{
39 Rey Cantor y Rey Anaya (1996), p. 157.

40 Ovalle (1998), p. 271.

41 Plascencia (2008).
} 
Pero no sólo se trata de un resguardo general de la eficacia de la respuesta jurisdiccional del Estado al momento de analizar los fundamentos y objetivos de una denominada función cautelar judicial, sino que ha de estar acompañado inseparablemente de una urgencia calificada que justifique una medida que en la mayoría de los casos tendrá como consecuencia el estancamiento de la dinámica económica patrimonial del afectado, y con ello, un perjuicio, a lo menos respecto de la opción de inversión de éste. Este segundo elemento terminaría de constituir el denominado periculum in mora.

Al continuar leyendo el precepto verificamos que su alcance teleológico no se limita a ese tradicional fundamento y objetivo, sino que, además, en virtud de la misma función cautelar, puede decretar alguna medida para: la protección de un derecho, la identificación de los obligados, y la singularización de su patrimonio. El juez podrá decretar "todas las medidas necesarias" para cumplir con dicha función, señala la propia ley, sin determinar en principio el contenido de las medidas mismas. Se deja de esta manera en blanco este elemento potestativo.

Hasta aquí no se hace mención expresa de los elementos clásicos y fundamentales que dan origen y sentido a las medidas cautelares, o las denominadas precautorias: el fumus bonis iuris y el periculum in mora ${ }^{42}$. De una u otra forma, pareciese que la función cautelar comprendida tal como lo hace el legislador, se extiende más allá de la tradicional comprensión asegurativa del resultado del juicio.

Basta con este primer inciso del artículo 444 para afirmar, como hace Juan Carlos Marín González, que "se reconoce explícitamente la existencia de una función cautelar [y que] debemos entender que el legislador ha querido referirse a una potestad cautelar genérica. En uso de esta facultad, el juez del trabajo puede adoptar cualquier medida que considere idónea para asegurar el resultado de la acción, la protección de un derecho, la identificación de los obligados y la individualización del patrimonio del obligado. De este modo el número, identificación y fines de la medida cautelar se ven ampliados considerablemente" ${ }^{\prime 4}$.

Gabriela Lanata, por su parte, en un sentido similar afirma que "tratándose de medidas prejudiciales y de medidas precautorias el Código de Procedimiento Civil procedía a enumerar las medidas procedentes, camino diferente al seguido

\footnotetext{
${ }^{42}$ MARín intenta relacionar el inciso cuarto del art. 444 CT con los elementos en cuestión, con el afán de salvar la situación un tanto extraña. Pero dicho ejercicio ni siquiera lo realiza directamente, sino de manera mediada por la ley procesal de familia, puesto que según su criterio, en ésta inequívocamente se aludía a los clásicos fumus boni iuris y periculum in mora. En ese sentido, señala que "Pareciera que la idea de fundamento razonable puede ser reconducida a la idea de verosimilitud (por oposición a certeza) empleada en materia de familia. Y la idea de necesidad podemos entenderla que engloba la idea de peligro de no satisfacción del derecho en sede provisional" MaRín (2006), p. 22.
}

${ }_{43}$ Marín (2006), p. 21. 
por la norma laboral, que impone al juez una función cautelar amplia"44. En el mismo sentido la Academia Judicial en su Manual de Juicio del Trabajo, al aceptar que se encarga una función cautelar al órgano jurisdiccional, y que "las medidas cautelares en juicio del trabajo son de una mayor amplitud respecto de aquellas aplicables en la antigua legislación, tanto desde los sujetos activos de las mismas, de la oportunidad para disponerlas, como del contenido de ellas" ${ }^{\prime 45}$.

$\mathrm{Si}$ el juez laboral tuviese efectivamente un poder genérico cautelar desprendido del precepto en cuestión, aquello significaría que puede decretar no sólo el número de medidas que estime idóneo para alcanzar uno de los cuatro fines cautelares establecidos en el precepto, incluyendo las modalidades clásicas, sino que al arriesgar una interpretación más laxa, la medida misma que decretará no tendría límite alguno, pudiendo tratarse de una cautelar nominada o innominada; conservativa o asegurativa; o inclusive de las denominadas innovativas, autosatisfactivas o anticipatorias.

He aquí el mayor problema. Al aceptar que la denominada "función cautelar del juez" equivale a la consagración de una potestad cautelar genérica, se abre la posibilidad de aceptar la dictación de medidas cautelares atípicas e innominadas, abriendo los objetivos y finalidades de "lo cautelar". Especial atención nos merecen las denominadas medidas innominadas, que pueden definirse como "aquellas no previstas en la ley, que puede dictar el juez según su prudente arbitrio, antes o durante el curso del proceso, con el objeto de prevenir que pudiera quedar ilusoria la ejecución del fallo o cuando hubiera fundado temor de que una de las partes puede causar lesiones graves o de difícil reparación a la otra" ${ }^{\prime 4}$. Desde otra perspectiva puede incluso realizarse una distinción como la siguiente: "con las medidas cautelares nominadas, se persigue garantizar las resultas del juicio, mientras que con las medidas cautelares innominadas, se evita de manera inmediata que una de las partes pueda causar lesiones graves o de difícil reparación al derecho de la otra" ${ }^{\prime 7}$, y por lo mismo, representan una posibilidad de intromisión patrimonial (y en casos incluso extrapatrimonial) mucho más grave. Es precisamente esta indeterminación potestativa la que abre ventanas a la arbitrariedad judicial, o la discrecionalidad sin elementos de control tipificado, lo que viene a significar lo mismo.

A propósito del punto anterior, Evelyn Morales señala que "la implementación de las medidas cautelares innominadas obedece a la subjetividad con la que los operadores de justicia acuerdan las mismas; quienes deben hacer

\footnotetext{
44 Lanata Fuenzalida (2010), p. 73.

45 Academia Judicial (2008), p. 64.

46 Rengel (1989), p. 91.

47 Morales (2008), p. 505.
} 
ejercicios de imaginación y aprendizaje a la hora de lograr su implementación en la praxis judicial, debido a que con la introducción de esta novedosa figura se han logrado notables modificaciones en la función pública de la administración de justicia" ${ }^{\prime \prime 8}$.

Tal como hemos señalado hasta este punto, no es concebible una atribución potestativa así de amplísima en nuestro ordenamiento jurídico, no sólo para el juzgador, sino para ningún órgano del Estado, pues aquello implicaría el reconocimiento de un ámbito abierto de libertad que no le es propio. De paso, se vulnera directamente uno de los cimientos del Estado de Derecho, cual es el principio de juridicidad, en su unión intensa con la certeza y seguridad jurídica, entregando a un órgano no idóneo potestades cuyos fundamentos son discutibles, y con ello, ampliando los ámbitos de restricción de libertad de los sujetos particulares, sin que sea necesaria deliberación democrática previa, que haya desembocado en la norma legal pertinente.

Desde otra perspectiva, más relacionada con la práctica misma del Derecho por parte de los operadores jurídicos en sede jurisdiccional, puede afirmarse que la apertura potestativa en cuestión pudiese dar lugar a mayores casos de actuaciones de mala fe (relacionadas clásicamente con situaciones de abuso de derecho), en las cuales el demandante utilice las medidas cautelares, más que como medios cautelares, como herramientas de amedrentamiento del demandado. La constatación de este hecho incluso ha llevado al profesor Peyrano ha sostener la creación de unas "medidas anticautelares". Al respecto señala que tales medidas apuntarían a "proscribir un ejercicio abusivo y excesivo de la potestad cautelar, circunscribiéndose a vedar que se concrete una medida cautelar en particular (una inhibición, por ejemplo) o la traba de una precautoria en relación de determinados bienes (embargos sobre las cuentas de una entidad aseguradora), cuando la realización de lo vedado importaría un grave perjuicio para el cautelado por afectar el giro de sus negociosy poder ser reemplazado ideológicamente por otra cautelar" ${ }^{\prime \prime 9}$. Dicho problema podría evitarse con menos complejidades e innovaciones teóricas de aquellos mismos que plantean incentivar el empoderamiento judicial. En efecto, bastaría con respetar el principio de juridicidad y la atribución potestativa típica conforme a las garantías de un justo y racional procedimiento, y debido proceso, para que los presupuestos de aplicación de las medidas cautelares respectivas se encuentren debidamente regulados, y no sujeten a las partes a situaciones de incerteza, inseguridad y desprotección.

48 Morales (2008), p. 507.

49 Peyrano, pp. 1-2. 
A pesar de lo anterior, hay quienes sostienen que sería coherente la inclusión de medidas cautelares innominadas (y atípicas) con el derecho fundamental a una tutela judicial efectiva, en atención a que cualquier derecho puede (y efectivamente está) sujeto a un daño por la demora. Así, por ejemplo, Rengel Romberg señala que "Bastaría recordar la función propia de las medidas cautelares en general, para no compartir [la] posición restrictiva [...] conviene observar que la tutela judicial de cualquier derecho, no escapa al peligro de la mora en el proceso, o del cambio o mutación de la situación de hecho existente al momento de la proposición de la demanda $[\ldots]^{\prime \prime 50}$. Sin embargo, desde dicha amplísima consideración cualquier pretensión resistida que sea demandada en sede jurisdiccional está expuesta al daño temporal, y el requisito de peligro en la demora pierde su significado. De hecho, desde aquella perspectiva no podríamos estar en condiciones de señalar por qué en algunos casos otorgamos medidas cautelares de tipo conservativo o anticipativo, y por qué en otros casos no. Esta situación se extrapolaría a todas las ramas del Derecho; nadie podría afirmar que, por ejemplo, un arrendador no se encuentra en urgencia de recibir lo devengado y adeudado por el arrendatario, a la vez que requiere la recuperación del inmueble en cuestión; podría tratarse de su única fuente de ingreso; pero luego, ¿bastará aquello para otorgar una medida cautelar innovativa o anticipativa?; ¿qué pasa con el arrendatario que simultáneamente recibe la notificación de la demanda y la notificación de una cautelar anticipatoria que ordena abandonar el inmueble retirando todos sus bienes de aquél?; y en último término, ¿qué pasa con el derecho a la defensa y el debido proceso?

En nuestro sistema jurídico no tienen lugar las atribuciones potestativas a órganos públicos mediante la utilización de cláusulas abiertas o en blanco, pues conforme al principio de juridicidad, y el de legalidad contenida en éste, las potestades deben contar, a lo menos, con ciertos elementos o caracteres mínimos que permitan reconocerla como tal. Añádase a dicha necesidad de actuar conforme a la ley por parte de los órganos públicos, el debido respeto al criterio de vinculación positiva, que en este caso particular se vería vacío de contenido, pues el texto normativo en cuestión pareciese definir solamente el elemento finalidad de la potestad (considerando cuatro alternativas de activación), sin enunciar en ningún caso los medios alternativos de los que dispondría el juez para su realización.

En este caso el elemento finalidad de la potestad cautelar otorgada se encuentra consagrado de manera expresa, pudiendo reconocer cuatro alternativas válidas fácilmente distinguibles entre sí. Encontramos por un lado a la clásica finalidad cautelar, consistente en asegurar el resultado de la acción; y por otro:

50 RenGel (1989), p. 87. 
la protección de un derecho, la identificación de obligados y la singularización de su patrimonio. Éstas constituyen las cuatro finalidades alternativas en virtud de las cuales se puede activar la función cautelar.

Aun en el análisis en el marco de la juridicidad pasaremos a ver cuáles son las formas de ejercicio de esta potestad que, de entrada, le estarían vedadas al juez. Para realizar dicha tarea tendremos en cuenta que, en virtud del principio de juridicidad, el juez debe respetar el debido proceso en la realización de las actuaciones procesales, y también las garantías procesales consagradas a nivel constitucional con que cuentan las partes.

\subsection{El debido proceso, y algunas modernas "medidas cautelares"}

Tal como señalamos en su momento, las peticiones cautelares se caracterizan esencialmente por su fin asegurativo o conservativo, en tanto sirven para "facilitar el resultado práctico de una futura ejecución forzada, impidiendo la dispersión de los bienes que pueden ser objeto de la misma" ${ }^{\prime 51}$. En tal denominación, las peticiones (o medidas) cautelares son portadoras de su concepción tradicional y clásica. Sin embargo, en derecho comparado se ha originado el debate sobre la posibilidad de que exista algún tipo de tutela cautelar con un fin diverso al conservativo, fundado en la garantía de tutela judicial efectiva.

En el debate procesal comparado uno de los ejes de discusión centrales ha consistido en la postulación o rechazo a ciertas novedosas medidas que supuestamente cumplirían un fin cautelar, pero que sin embargo han terminado por transformarse en instituciones autónomas, con fines propios y presupuestos bastante discutibles. Fundamentalmente su creación jurisprudencial y doctrinaria vendría a satisfacer una urgente necesidad de tutela judicial efectiva, ante lo engorroso y extensivo que se ha vuelto en la práctica la tramitación de un juicio ordinario, y la consecuente inoportuna entrega de justicia para las partes litigantes que esto viene a significar ${ }^{52}$. Con dicha orientación son conocidas hoy las denominadas medidas innovativas y las medidas (sentencias) autosatisfactivas. Compartirían éstas, una supuesta finalidad anticipativa (por oposición a la tradicional asegurativa o conservativa), precisamente fundadas en la supuesta urgencia por tutela judicial en que se encontraría el peticionante.

\footnotetext{
51 Calamandrei (1945), p. 56.
}

52 "[...] frente a uno de los principales problemas que comporta la denominada crisis de la Justicia civil, cual es el de la excesiva duración de los procesos, se hace un Ilamado a pensar en tutelas diversas de la ordinaria, cuando el peligro que comporta para los derechos e intereses legítimos de los ciudadanos una decisión jurisdiccional "tardía" así lo aconseje, como son las que se denominan tutelas de urgencia, ya sean sumarias, autosatisfactivas, cautelares innovativas o simplemente cautelares, etcétera, que permiten otorgar la necesaria tutela jurisdiccional al ciudadano que la reclama del Estado, en unos plazos mucho más breves que la tutela ordinaria" Bordalí (2001), p. 52. 
Las cautelares innovativas, traducidas hoy en la orden de innovar en la situación jurídica actual, o en la facultad para alterar el statu quo, son expresión manifiesta de un anticipo judicial. Tal como se desprende de la expresión, es una medida decretada por el juez que tiene como finalidad alterar la realidad actual y los espacios de libertad existentes para las partes, previo a la realización completa del Proceso. En palabras del profesor Alvarado Velloso, en virtud de ésta "el actor trata de alterar una situación fáctica sobre la cual no ha empezado aún la discusión procesal y que desea evitar obteniendo, anticipadamente y sin previa discusión, el resultado que debe ser el necesario contenido de la sentencia a dictar en un litigio después de transitar todas las fases de un proceso regularmente llevado, con previa y completa audiencia de ambos interesados" ${ }^{\prime 53}$. Dentro de este grupo de cautelas innovativas encontraremos a la denominada tutela cautelar anticipatoria, que ha sido concebida como accesoria a un proceso principal, en virtud de la cual se anticiparían provisoriamente los efectos de la sentencia definitiva, en espera del posterior desarrollo del contradictorio. El inicio de este nuevo recorrido de lo cautelar ha desembocado, por su carácter anticipatorio, en un conjunto de medidas que parecen cada vez buscar más su autonomía respecto de un proceso principal. Con esto, perderían uno de los caracteres propios y tradicionales de lo cautelar, cual es la instrumentalidad de las medidas decretadas en relación con las peticiones de fondo.

En este sentido ha expuesto Cipriani a propósito de la experiencia procesal italiana, al señalar que "[e]n realidad esas resoluciones, una vez privadas de aquella característica y transformadas sustancial o potencialmente autónomas respecto al juicio de fondo terminan siendo cautelares solo por así decirlo, tanto que desde ahora deberían ser netamente distinguidas de las verdaderas resoluciones cautelares, las medidas conservativas, y tanto para inducirnos a afirmar que ya la tutela cautelar anticipatoria se ha transformado en tutela sumaria no definitiva $[\ldots]^{\prime \prime 54}$

Por otro lado, pero con el mismo espíritu, encontramos a las medidas autosatisfactivas, que "consisten en el otorgamiento inmediato por un juez del derecho pretendido por un actor civil, a su solo pedido y sobre la exclusiva base de la aceptación unilateral y sin más que la autoridad hace respecto de la existencia de ese derecho" ${ }^{\prime \prime 5}$. A diferencia de la anterior medida, ésta claramente es una forma autónoma e inmediata de otorgar satisfacción a lo pedido, inaudita et altera pars, que sólo eventualmente dará origen a un Proceso posterior (he aquí la principal diferencia), en caso de que el afectado con la medida ejecutada

\footnotetext{
53 Alvarado (2008), p. 91.

${ }^{54}$ Cipriani (2007), p. 313.

55 Alvarado (2008), p. 95.
} 
impugne la resolución que se dictó en su contra, o, dependiendo de la construcción doctrinaria o legal respectiva, si el juez así lo decidiese, por ser él mismo quien de oficio desecha la petición solicitada. En este caso, tal como señala Bordalí, "[l]a tutela cautelar, no ligada a un proceso "principal" con el carácter de necesariedad, sino ya sólo ocasionalmente, y como tal, autosatisfactiva de la relación jurídica sustancial tutelada, expresaría que las providencias cautelares han ido asumiendo paulatinamente una cabal autonomía, en el sentido que valen por sí mismas, en tanto constituirían muchas veces la única forma, y no ya de modo subordinado a los resultados de un proceso de mérito ulterior" ${ }^{\prime \prime 56}$.

Con las medidas autosatisfactivas lo cautelar ha tomado otro cariz, y antes que propiamente cautela o conservación, ha devenido en anticipación por urgencia. En anticipación sumaria en razón de la naturaleza de lo solicitado por el demandante, y en especial porque aquí el peligro en la demora no se limitaría a un perjuicio patrimonial reparable, sino que abarcaría hipótesis de daño irreparable, de cautela urgente. Podríamos incluso afirmar que más que peligro en la demora, estamos en presencia de un tercer elemento, cuál es el daño o lesión irreparable de un derecho del demandado, que requeriría tutela urgente. Es precisamente en este lugar en donde las medidas innominadas toman un papel central, pues radicarían en el juez una atribución potestativa general "para asegurar o garantizar que no se le cause un daño o perjuicio inminente o de difícil reparación al derecho de una de las partes durante el proceso, resguardando así uno de los fines principales del derecho, formado por la aplicación de una justicia, rápida, eficaz (sic)" ${ }^{\prime \prime 7}$. La urgencia pasa a ser el elemento genérico que contiene a lo cautelar, pero no se agota en él, y toma como una de sus manifestaciones a esta variante autosatisfactiva.

En virtud de la denominada "potestad cautelar genérica" supuestamente implícita en la función cautelar del juez, podría aventuradamente sostenerse que éste puede decretar una medida cautelar innominada que coincida con las formulaciones correspondientes a las medidas cautelares innovativas y autosatisfactivas. He ahí el principal problema hermenéutico al abordar la atribución normativa contenida en el artículo 444 inciso primero, pues en ese ejercicio debemos respetar siempre al principio de juridicidad. En efecto, se ha afirmado en derecho comparado que uno de los rasgos típicos de estas medidas, junto a la situación de urgencia y la probabilidad de que el derecho sea atendible, es que "[h]asta tanto se regule legalmente la medida autosatisfactiva, puede fundamentarse su dictado en la potestad cautelar genérica o en una válida interpretación analógica extensiva de las disposiciones legales que expresamente disciplinan

56 Bordalí (2001), p. 58.

57 Morales (2008), p. 511. 
diversos supuestos que pueden calificarse como medidas autosatisfactivas" ${ }^{\prime 58}$. No podía ser más claro.

Señala Alvarado Velloso, sobre los autores partidarios de la doctrina cautelar en cuestión, que "sin reparar en la naturaleza obviamente diferente que muestran una verdadera cautela y lo que en los últimos años ha dado en Ilamarse solución jurisdiccional anticipada so pretexto de una tutela judicial efectiva, han fincado toda anticipación de sentencia en ese preciso poder cautelar genérico" ${ }^{\prime \prime 59}$.Si reconociésemos en la norma citada un poder cautelar genérico podríamos dar cabida a la doctrina en cuestión, sin embargo, tal como pasaremos a revisar, las medidas innovativas y autosatisfactivas no tienen cabida en nuestro ordenamiento jurídico, aun si aceptamos que la norma consagra un poder cautelar genérico, por vulnerar éstas las normas del debido proceso.

La medida cautelar innovativa afecta la esfera de libertad de aquella parte en contra de quien se decreta sin que se hayan oído previamente sus alegaciones, con lo que se afecta inmediatamente de manera grave su derecho a defensa en juicio. Deberá soportar en muchos casos los mismos efectos que tendría una sentencia, antes de haber sido oído. Con ello la supuesta naturaleza "cautelar" de la medida queda descubierta como anticipación de la sentencia por parte del juez. La desnaturalización de la cautela se hace evidente; en este caso en nombre de cautela se realiza un prejuzgamiento en contra de una de las partes habiendo oído sólo a su contendora, quedando abandonado el primero a las más burda desprotección. Podrá eventualmente presentar sus alegaciones posteriormente, sin embargo el prejuzgamiento ya fue hecho por parte del juez, y entonces no se enfrentará en juicio sólo a su contraparte, sino también al preconvencimiento del juez que ya ha expresado su opinión públicamente.

La medida autosatisfactiva es mucho más grosera en su vulneración al derecho a defensa, pues ni siquiera supone como necesario un Proceso contemporáneo principal que defina su accesoriedad, ni menos uno posterior que pueda arrojar como resultado la retractación de la medida, y la correspondiente indemnización de perjuicios. Resuelve instantáneamente el litigio, no necesitando la realización de un proceso principal para llegar a lograr la exigibilidad correspondiente de lo dispuesto en la resolución; en otras palabras, condena sin haber oído a la contraparte, sino bastando la alegación unilateral del peticionante. De hecho, es tal la lejanía de esta supuesta medida, aunque sentencia al fin y al cabo, con las tradicionales peticiones cautelares, que abandona la

58 Bisogno (2003).

59 Alvarado (2008), p. 89. 
característica accesoriedad a un proceso principal, y la provisionalidad de la misma, como elementos definitorios clásicos ${ }^{60}$.

Podríamos aventurar en este punto que la tutela cautelar anticipada configurada de la forma expuesta está más cercana a lo que nuestro legislador consagró como Procedimiento Monitorio. En efecto, a pesar de tener la nominación de Procedimiento monitorio, dado por el legislador, el nuestro se aleja bastante de las formas monitorias europeas, y se acerca mucho más a lo que se ha denominado tutela anticipada. Así, Palavecino y Ramírez afirman que "la doctrina iuslaboralista nacional ha obviado -posiblemente de manera interesada- las diferencias sustantivas que existen entre nuestro procedimiento monitorio laboral y las formas monitorias europeas" ${ }^{\prime 61}$. El juez laboral podrá dictar como primera providencia una resolución que acoja la demanda total o parcialmen$t^{62}$, quedando bajo su apreciación la eventual necesidad de iniciar un diálogo procesal bilateral posteriormente, o pronunciándose directamente sobre el fondo del asunto, dejando la posibilidad a las partes de iniciar un contradictorio sólo en el caso eventual de que éstos presentasen reclamo de la resolución que acoge o rechaza la petición, dentro de décimo día. Al respecto compartimos la opinión de que "si la urgencia en la protección del derecho se utiliza como justificativo de la adopción de medidas que tienen valor sustantivo y por lo tanto definitivo, se traspone el límite que marca la exigencia constitucional"63, y en nuestro caso particular, la garantía de contar con un justo y racional proceso que sea respetuoso del derecho a defensa de las partes. Esta verdadera tutela anticipatoria se vuelve aún más vulneratoria si no es comprendida de manera accesoria y ligada necesariamente a un proceso principal, sino que de manera autónoma e independiente.

Por otro lado, si bien toda petición cautelar da origen a un mero procedimiento y no a un Proceso ${ }^{64}$, entre otras cosas porque es una dictación que requiere esencialmente la participación sólo de dos agentes, y no de tres, como requiere el segundo, el contenido de la resolución coincide con aquello que debiese ser resultado de la discusión dialéctica entre dos partes frente a un juez

${ }^{60}$ Lo mismo cabe decir sobre la confusión que se produce con los conceptos de fumus boni iuris y periculum in mora.

${ }^{61}$ Palavecino y Ramírez (2010), p. 73.

62 Art. 500 "En caso que el juez estime fundadas las pretensiones del demandante las acogerá inmediatamente; en caso contrario las rechazará de plano [...] en caso de no existir antecedentes suficientes para este pronunciamiento, el tribunal deberá citar a la audiencia establecida en el inciso quinto del presente artículo".

${ }^{63}$ Bisogno (2003), p. 6.

${ }^{64}$ Estamos en presencia de una relación jurídica entre dos agentes, guiada por el principio jerárquico en virtud del ejercicio unilateral de una potestad, y no frente a una relación triangular perfecta que configuraría la forma del proceso. 
tercero imparcial. En otras palabras, con estas "modernas" medidas cautelares se pretende anticipar el contenido del resultado de un Proceso, sin la realización de éste; la anticipación es siempre anticipación de una de las pretensiones, por tanto, aquello que se está otorgando con esta medida es simplemente el natural resultado final del litigio, que debiese estar contenido en la sentencia que da término a un Proceso previo legalmente tramitado.

El juez laboral no puede pretender decretar una de estas modernas medidas en virtud de la potestad que le otorga el art. $444 \mathrm{CT}$, ya que ni en la tutela anticiparía ni en la medida autosatisfactiva se respeta el debido proceso ni el derecho a defensa. De hecho, al hacerlo, en el caso de las medidas autosatisfactivas, dejaría de ejercer su función jurisdiccional, pues podría resolver el conflicto intersubjetivo entre partes sin la realización del Proceso correspondiente. Actuaría fuera de las atribuciones normativas impuestas desde nuestra norma fundamental.

En todo caso, es evidente que existen situaciones especiales que requieren de una solución urgente. Aquello no está en discusión. Sin embargo, no podemos escondernos tras dicha urgencia para incrementar irracionalmente los poderes jurisdiccionales, a la vez que violentamos un sinnúmero de garantías constitucionales, y dejamos de lado al Proceso mismo, como un medio pacífico de solución de conflictos intersubjetivos. El legislador ya ha establecido (por ejemplo, en el caso de los alimentos provisorios) ciertos casos en que dicha urgencia amerita una tutela anticipada, y podría seguir haciéndolo de estimarlo conveniente, más no es función del juez, ni cuenta con la legitimidad democrática, para tomar decisiones, caso a caso, sobre la supuesta necesidad o urgencia de la respectiva pretensión. Incrementar los poderes judiciales en este sentido, terminará atrayendo más dificultades que bondades para el Poder Judicial en su conjunto. Podría el legislador inclusive tomar vías alternativas mediante la creación de juicios sumarísimos, para la oportuna satisfacción de los derechos, sin obviar en ningún caso la realización previa de audiencias para oír a ambas partes, respetar la bilateralidad del juicio, el principio del contradictorio, y en general, el debido proceso garantista.

Por otro lado, es precisamente la naturaleza especial de determinados derechos, y su eventual daño o vulneración, los que justificarían la dictación de medidas cautelares innovativas, fundadas en una potestad cautelar general. En este sentido, las medidas cautelares y provisionales anticipatorias han tenido una especial utilidad en el resguardo de los derechos fundamentales. Mas, si nos acercamos a la naturaleza de los derechos reclamados en sede laboral nos encontramos con que son básicamente derechos de tipo patrimonial los que son el objeto de la litis (salvo en el caso del procedimiento de Tutela). Sin embargo, al respecto habría que abordar un análisis particular que permita justificar el carácter alimentario de lo demandado en sede laboral; sólo superando dicho 
obstáculo podría otorgarse un fundamento sólido que guíe hacia una discusión democrática en donde se fije de manera definitiva el carácter alimentario de los derechos laborales. No podemos estar a lo que decida cada juez, en tanto agente independiente. Sería beneficioso para la seguridad jurídica y el funcionamiento del sistema todo el que un tema así de trascendental quede resuelto en un texto normativo emanado de los órganos correspondientes, y de aquella manera evitar mayores discusiones.

Una consagración legal que se hace cargo de la particularidad de los derechos tutelados encontramos en el Procedimiento de Tutela. En particular en la fórmula contenida en el artículo 492 del Código del Trabajo, que señala lo siguiente:

"Art. 492. El juez, de oficio o a petición de parte, dispondrá en la primera resolución que dicte, la suspensión de los efectos del acto impugnado, cuando aparezca de los antecedentes acompañados al proceso que se trata de lesiones de especial gravedad o cuando la vulneración denunciada pueda causar efectos irreversibles, ello, bajo apercibimiento de multa de cincuenta a cien unidades tributarias mensuales, la que podrá repetirse hasta obtener el debido cumplimiento de la medida decretada. Deberá también hacerlo en cualquier tiempo, desde que cuente con dichos antecedentes.

Contra estas resoluciones no procederá recurso alguno".

En este caso, si bien existe una consagración expresa en la ley que otorga al juez la potestad de decretar la suspensión de los efectos del acto impugnado, cumpliendo al menos con el principio de juridicidad en tanto potestad tipificada, al realizar un análisis desde el debido proceso, nos cabe la posibilidad de criticar la imposibilidad de recurrir de la resolución en cuestión, y con ello eliminar el contradictorio, y la bilateralidad. En otras palabras, es manifestación de la función cautelar iusfundamental del juez del trabajo, sin embargo, su forma anticipatoria es contraria a lo prescrito por el contenido del debido proceso. Estamos ante un prejuzgamiento, que sin duda, tendrá efectos sobre la solución de fondo, y que por estar ubicada precisamente en el procedimiento de tutela de derechos fundamentales del trabajador, abre las posibilidades de decretar providencias desde la interpretación del contenido de los derechos fundamentales que entren en debate litigioso.

Hasta aquí incluso se vuelve sobreabundante analizar el prejuzgamiento que significa por parte del juez pronunciarse sobre el fondo del asunto al iniciar el proceso, sin oír a la contraparte, , simplemente con haber analizado livianamente la verosimilitud de la pretensión alegada unilateralmente, lo que atenta contra el principio de igualdad de las partes y afecta directamente la imparcialidad del juez que será el mismo que a la postre terminará fallando sobre el conflicto. 
Por último, existe un argumento de texto que permite limitar hermenéuticamente la supuesta potestad cautelar general, y determinar el contenido del "cómo", en la realización dinámica de su facultad. El artículo 444 en su inciso segundo indica "Con todo, las medidas cautelares que el juez decrete deberán ser proporcionales a la cuantía del juicio", luego, si la propia ley señala de manera expresa que la cautela ha de ser proporcional a la cuantía del juicio, es porque supone que los derechos litigiosos han de ser siempre avaluables pecuniariamente en el texto de la demanda. En efecto, la parte petitoria del libelo demandante ha de contener una suma cierta y determinada, que servirá de base para la determinación de la cuantía del juicio. Con ello, el interés perseguido por el trabajador será en todo caso un interés patrimonial, directo o indemnizatorio por equivalencia. Tal vez la única excepción la encontremos en la consagración del Procedimiento de Tutela, en donde se persigue la cesación de medidas vulneratorias de derechos fundamentales, y también su resarcimiento. Pero, tal como hemos señalado previamente, el legislador en atención a la particular naturaleza de los derechos aquí vulnerados, ha consagrado una norma específica en el art. 492, que permite indicar que hay en ese caso un ejercicio de la función cautelar.

Si las medida decretadas, todas, sin excepción, conforme a la ley han de ser proporcionales a la cuantía del juicio, dicha proporcionalidad ha de tener un estándar de comparación pecuniario y patrimonial, estándole vedada la posibilidad de decretar medidas innovativas atípicas de otro tipo (cerrar establecimiento, ordenar realización de determinadas actividades en la empresa, publicación previa de avisos con contenido reparatorio, etc.). En ese sentido, el legislador parece apegarse en este punto de vuelta a la noción asegurativa de las facultades cautelares.

\subsection{Las "medidas cautelares especiales"}

El artículo 444 CT amplía el abanico de fines posibles a perseguir tras la dictación de una medida cautelar. Excluyendo las ya mencionadas medidas innovativas y las autosatisfactivas, por no tener cabida en nuestro ordenamiento jurídico como cautelares innominadas, podemos afirmar que se mantiene la tradicional finalidad cautelar conservativa o asegurativa, en tanto se autoriza expresamente al juez a decretar la medida que estime necesaria para asegurar el resultado de la acción, pero además nuestro Código sorprende con tres nuevas finalidades de la función cautelar: la protección de un derecho, la identificación de los obligados y la singularización de su patrimonio.

Es evidente que ninguna de estas tres finalidades guarda mayor similitud con la tradicional petición cautelar con finalidad eminentemente conservativa y asegurativa del resultado del juicio, y más aventurado es aún relacionarlas 
con los tradicionales fundamentos o requisitos de periculum in mora y fumus boni iuris.

Al respecto, el Manual de Juicio del Trabajo de la Academia Judicial señala que "se puede hacer la distinción entre las medidas cautelares especiales, propias del objeto específico de la controversia laboral, y aquellas cautelares generales comunes a otros procedimientos" ${ }^{\prime \prime 5}$. Con esto último parece referirse a aquellas tradicionales asegurativas del resultado de la acción que son reguladas en el Código de Procedimiento Civil, y que son aplicadas supletoriamente no sólo en el caso del Proceso laboral, sino también en otras ramas del Derecho.

Sobre la medida cautelar que consiste en la protección de un derecho, el texto legal no realiza mayor profundización, y parece dejar abierta la puerta nuevamente al imaginario judicial. Sin embargo, como ya señalamos previamente, no existe una libertad o arbitrio absoluto para los jueces en este nivel potestativo. Más que una medida o petición cautelar, pareciera ser una medida de protección de carácter autónomo. Sin embargo, aun arriesgando confusiones, hay que aclarar que dicha medida jamás puede significar anticipo de la solución de fondo de la litis, sin que medie un Proceso previo. Pero pareciera que la intención de la norma es que el juez tenga facultades cautelares respecto de derechos que no necesariamente son materia de la litis, pues respecto de éstos ya estableció la clásica finalidad cautelar conservativa o aseguradora del resultado de la acción. Si no se trata de uno de los derechos en que se funda alguna de las pretensiones, debe entenderse entonces que primordialmente la función cautelar en este sentido se orienta a la realización y resguardo de la juridicidad del debate mismo en el Proceso. En ese sentido, se encarga al juez la protección de los derechos que no son el eje de discusión, pero que pueden verse afectados en el desarrollo de ésta. Reiteramos que el ejercicio de la facultad cautelar no puede significar la protección de un derecho totalmente ajeno al objeto del Proceso mismo, o las garantías que rodean su correcta realización, pues en tal caso, la medida cautelar se transformaría en una medida innovativa o incluso anticipativa de un litigio que ameritaría un desarrollo procesal paralelo, y el juez podría pronunciarse sobre materias que no han sido llevadas a estrado por las partes, vulnerando con ello el principio dispositivo. El afán justiciero que se puede esconder tras la función cautelar del juez no puede extender su alcance más allá de la materia del juicio definida por las partes.

En síntesis, la función cautelar que faculta al juez a decretar medidas para la protección de un derecho, no puede traducirse en una medida innovativa innominada, en una medida cautelar autosatisfactiva, ni en general, en una sentencia anticipada que termine por vulnerar los derechos de otro titular, sin

65 Academia Judicial (2008), p. 65. 
haber realizado un Proceso previo. La forma correcta de realizar esta función ha de mirar siempre al respeto al debido proceso, y las garantías individuales de las partes, sean procesales, patrimoniales.

La tercera y cuarta finalidades supuestamente cautelares, consistentes en la identificación del obligado y la singularización de su patrimonio, evidencian una vez más el rol activo del juez en Proceso laboral, y la orientación activista del legislador. Parece que la función cautelar del juez, desde una comprensión tradicional asegurativa, se ha desnaturalizado al punto que en virtud de ella el juez debe ahora velar por la satisfacción positiva del interés de una de las partes, ya no de manera imparcial sobre el objeto del litigio mismo. En una afirmación bastante equívoca en la terminología y un tanto confusa, la Academia Judicial señala en su manual que la función cautelar en este caso consideraría lo "que importa una hipótesis de abuso procesal o de instrumentalización de la persona jurídica con la finalidad de confundir, ocultar, disminuir o de sustraer al que naturalmente ha de resultar obligado como consecuencia de tener la calidad de deudor de obligaciones laborales o previsionales"66. En este caso se intenta armonizar forzosamente lo enunciativamente cautelar con la visión eminentemente activista que tuvo nuestro legislador al crear el nuevo Proceso laboral, sin embargo, en tal intento, se genera una tensión irresoluble. De función cautelar, pareciese que pasa a transformarse decididamente en función probatoria, que por su naturaleza, no le corresponde en absoluto al juez, en su posición tercero imparcial.

A través de las potestades cautelares entonces no sólo se velaría por la eficacia del resultado de la acción, en el sentido de evitar una ausencia de contenido patrimonial del demandado que enajenaría, de mala fe, bienes suyos para evitar el cumplimiento de que eventualmente se ordenará, sino que aquí derechamente el legislador ha pasado ha otorgarle una finalidad, más que cautelar, eminentemente protectora del juez laboral respecto de la pretensión incoada en juicio. Se arriesga sacrificar la imparcialidad del juez encomendándole labores investigativas que pueden ser ejercidas oficiosamente, y que beneficiarán sistemáticamente a una de las partes del juicio.

Defendiendo el rol activo del juez a través de esta cautelar, considerándola como una facultad pseudoprobatoria, Gabriela Lanata señala que "muchas veces las pruebas en tal sentido pueden ser dificultosas para el trabajador. Dentro del nuevo procedimiento se otorgan facultades al juez para que asuma la iniciativa. Así, se le autoriza, aun sin necesidad de petición de parte recurrir a oficios, por ejemplo, al Servicio de Registro Civil, Servicio de Registro Electoral, Servicio

66 Academia Judicial (2008), p. 65. 
de Impuestos Internos, con el fin de determinar tales elementos" ${ }^{\prime \prime 7}$. Por su parte, en palabras utilizadas en el manual de la Academia Judicial, "el legislador ha establecido que el juez debe disponer una verdadera investigación que lo lleva a asegurar los resultados de la acción" ${ }^{\prime 68}$.

Nada más claro que lo anterior; se ha encomendado al juez laboral hacerse parte y colaborar en la indagación probatoria, en beneficio del trabajador. Pero, tal como es comprendida la facultad en cuestión se genera una relación tensa con el último tipo de medidas cautelares, esto es, con la "singularización del patrimonio". Haciendo una interpretación armónica de la norma junto al actual artículo $3^{\circ}$ inciso $4^{\circ}$, y artículo 507, propios de la denominada "Ley Multirut", nos es dable pensar que la singularización de patrimonio en este caso incluye sólo una constatación material objetiva de los derechos que tenga el demandado sobre determinados bienes, y la realización de inventario de aquellos, con la finalidad de posteriormente asegurar el cumplimiento, mediante medidas conservativas.

En este sentido, la labor del tribunal consistirá sólo en otorgar medios para la identificación detallada de los bienes en cuestión, y así otorgar una medida cautelar conservativa, pero en ningún caso puede traspasar dicho límite y entrar a investigar y buscar pruebas de casos de simulación o subterfugio, en donde varios patrimonios (personas jurídicas) se encuentren vulnerando la ley con la finalidad de obviar sus obligaciones laborales. O dicho de otra forma, no es esta vía cautelar el mecanismo idóneo para iniciar una investigación de grupos de empresas que actúen como un empleador para efectos laborales. Para ello el propio legislador ha consagrado normas particulares que ordenan su tramitación conforme a las reglas del procedimiento ordinario. Debe decretar medidas que persigan la individualización del contenido patrimonial del demandado, mas no le corresponde añadir nuevos patrimonios que respondan ante la pretensión.

La actuación oficiosa del juez en el sentido descrito se encamina al descubrimiento de una situación o hecho de relevancia jurídica que debiese ser alegado por las partes y probado por ellas mismas, como es la simulación de contrato, o inclusive el eventual fraude a la ley laboral, por tratarse de cuestiones sustantivas que ameritan ser discutidas contradictoriamente en el marco de un debido proceso. A tal punto llega la aventurada travesía potestativa, que se afirma, de lo expuesto, y a propósito de la potestad cautelar, que "la ley procesal asume la doctrina del levantamiento del velo, en cuanto se le reconocen al juez las facultades necesarias para establecer el ámbito de responsabilidades

67 Lanata (2010), pp. 72-73.

68 Academia Judicial (2008), p. 65. 
con prescindencia de los aspectos formales [... $]^{\prime \prime 69}$, olvidando completamente que como contradictor se encuentra también un titular de derechos; existe una persona, natural o jurídica, respecto de la cual una actuación como la descrita puede terminar significando una vulneración iusfundamental, no tan sólo en el ámbito procesal, sino incluso en relación a otras garantías, como la libertad de asociación.

En el fondo, el sentido que se ha querido otorgar a estas dos finalidades cautelares, es evidentemente inquisitivo, y esconde tras de sí mucho más que la tradicional función cautelar, pues llega a inmiscuirse en asuntos que son materia de prueba, y respecto de las cuales deben ser las partes quienes se encarguen de confirmar las pretensiones respectivas.

Sin más, se ha pretendido deducir atribuciones potestativas judiciales que inciden directamente en el contenido probatorio de la litis, desde una función cautelar que permitiría afirmar una potestad cautelar general y abierta. Sin duda, siguiendo este camino, lo cautelar ha perdido su propia significancia, y siendo vulgarizado, pretende servir de bastión de lucha publicística. Parece que no sólo la celeridad era el problema, sino que se necesitaba despejar las dudas respecto del nuevo rol protagónico del juez laboral.

En último término, esta potestad inquisitiva vulnera los principios del debido proceso, y pareciera fijar el establecimiento de un sistema inquisitivo, antes que uno garantista que sería coherente con nuestra Constitución.

En general, todas las medidas cautelares hasta aquí descritas pueden iniciarse a petición de parte o directamente de oficio ${ }^{70}$ (según Lanata "el inciso primero del artículo 444 [...] le ordena al juez (no sólo lo faculta) decretar todas las medidas necesarias para: a)asegurar el resultado de la acción; b)la protección de un derecho; c)la identificación de los obligados; y d) la singularización de su patrimonio"71), respondiendo fielmente al espíritu inquisitivo que rige la totalidad del proceso laboral. He ahí el mayor problema, pues en el fondo, al interpretarse de esta manera la norma en cuestión, el juez contará con facultades investigativas, probatorias y cautelares oficiosas, que pueden ser puestas en ejercicio incluso previo a la notificación de la demanda. Luego, en el desarrollo mismo del juicio, puede continuar su labor inquisitiva, por ejemplo, requiriendo oficiosamente información de organismos públicos, u otra persona jurídica $o$ natural (inciso quinto art. $444 \mathrm{CT}$ ).

Debemos recordar que no es deseable que la persona encargada de investigar sea la misma que termine por juzgarnos; dicha diferenciación en las

\footnotetext{
${ }^{69}$ ACAdemia Judicial (2008), p. 66.

70 Academia Judicial (2008), p. 66; y además, Lanata (2010), p. 73.

71 Lanata (2010), p. 73.
} 
funciones es una de las garantías procesales fundamentales que la modernidad ha ganado en nombre de la libertad. Esta garantía es ampliamente aceptada en el Proceso Penal, y no existe razón para comenzar a retroceder en el resto de las subramas procesales.

\subsection{Algunos casos de uso de la "potestad cautelar genérica" por los Juzgados del Trabajo}

Quién haya sido el lector que acompañó hasta este punto nuestro diálogo esperará encontrar al menos la mención de un par de casos "prácticos"; algo de evidencia jurisprudencial que permita sustentar lo grave de nuestras advertencias. Sin duda es ardua la labor de indagar por la presencia de resoluciones del estilo referidas toda vez que éstas pueden ser dictadas y solicitadas durante todo el transcurso del proceso (incluso antes de ser notificada la demanda) ${ }^{72}$. Así, no es recurrente encontrar en las bases de datos usuales la referencia a las mismas, a menos que hayan sido objeto de algún recurso, y en virtud de aquél, haya sido revisada la respectiva resolución por los Tribunales Superiores de Justicia.

Sin embargo, hemos encontrado un par de casos ejemplares que nos serán útiles para graficar la actuación dinámica de la cuestionada potestad.

El primero de los casos trata del ejercicio de la función cautelar que nos parece menos gravosa para el derecho a defensa de las partes, esto es, el decretar una medida cautelar precisamente a solicitud de una de las partes, aunque no se encuentren tipificados de manera íntegra los elementos constitutivos de los mismos. Hablamos de una resolución dictada el 18 de febrero de 2014 por el

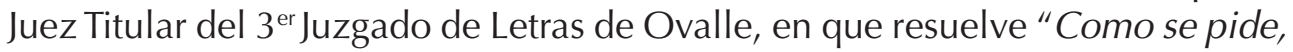
oficiándose al efecto" en autos laborales Rit T-3-2013. ¿Cuál había sido la petición de la parte? Ésta indica que en virtud de lo prescrito en el artículo 444 del Código del Trabajo se sirva el tribunal decretar la retención de dinero hasta un monto " $\mathrm{x}$ " que el demandado principal pudiera tener a su favor como prestador de servicios de la demandada solidaria. Sin hacer remisión expresa a las normas supletorias de los artículos 290 y ss. del Código de Procedimiento Civil, ni recurriendo a más fundamento legal que el contemplado en el texto normativo del artículo 444 del Código del Trabajo, la parte ha Ilamado al ejercicio de la función cautelar genérica del juez del trabajo, obteniendo por parte de éste una acogida satisfactoria, pero que no aborda tampoco de manera abundante el fundamento legal del ejercicio de la función cautelar, y la medida cautelar resultante, dándonos a entender que le ha bastado la razón argumentativa

${ }^{72}$ De una u otra manera esta característica se relaciona con la naturaleza jurídica de la resolución que dicta una medida cautelar, que se bate entre ser determinada como un auto, por un lado, o como una sentencia interlocutoria, por otro. 
otorgada por el peticionante, esto es, que la norma del artículo 444 consagra una potestad atípica; abierta.

Otro ejemplo, que ya pone en tránsito dinámico la función cautelar del Tribunal, lo encontramos en la sentencia definitiva dictada por el Juzgado de Letras, Garantía y Familia de Aysén, en causa Rit O-2-2010, en fecha siete de abril de 2010. En dicha resolución, en la parte dispositiva, señala literalmente:

"Que a fin de cautelar los derechos laborales eventuales del demandantes en conformidad a lo establecido en los artículos 444 y 425 del Código del Trabajo, reitérese el oficio al Registro Civil para que informe acerca de la existencia de bienes asociados al rut del empleador demandado, el que deberá cumplirse dentro de quinto día bajo apercibimiento de los artículos 238 del Código de Procedimiento Civil y 253 del Código Penal.- Ofíciese".

El tribunal utiliza retóricamente el artículo 444 a fin de fundar una anticipación diligenciosa en vista de la futura ejecución de lo resuelto condenatoriamente. Sin embargo, y como ya habrá de haber imaginado el erudito lector, dicha anticipación omite la posibilidad de recurrir ante la propia sentencia judicial a través de un recurso de nulidad. Dicta sentencia y en el acto inicia las diligencias propias de la etapa de cumplimiento. Estamos conscientes de que la celeridad ha sido uno de los fundamentos sustanciales que han moldeado la ideación de los nuevos procedimientos laborales, sin embargo el espíritu progresista que riega su fértil intención en los Tribunales del Trabajo no puede pretender omitir al menos las ordenaciones básicas de las reglas procedimentales en el ejercicio de la jurisdicción. No porque sea un preciosismo técnico el pretender su conservación fundamental (distinguir entre procesos de cognición y ejecución, como mínimo) sino porque estas nociones son manifestaciones de un derecho fundamental anterior; el derecho a defensa de las partes, y el derecho a un debido proceso.

A diferencia del primer caso de análisis, sobre retención patrimonial, y limitación a libre circulación de los bienes, la presente resolución resulta menos intrusiva en su forma de realización, pues se basta en una indagación, que de no prosperar la etapa de ejecución, no afectaría mayormente al sujeto respecto del cual se informará la existencia o no de bienes, suponiendo que el carácter público de la información solicitada no alteraría la integridad iusfundamental del "eventual" condenado. Tal vez el reverso negativo que se desprendería de una comparación (por cierto disímil) con la resolución anteriormente referida aparece de la circunstancia de haber sido esta última dictada oficiosamente por el juez (la primera fue dictada a petición de parte, ciñéndose a la solicitud), que reafirma nuestra hipótesis de que la norma está "puesta ahí", para que los jueces puedan desde ellas desenvolver sus ideaciones prácticas, no sólo respecto de 
la oportunidad de su dictación (en este caso fue al momento de la dictación de la sentencia definitiva), sino también en cuanto a su contenido.

Un tercer tipo de carácter diverso a los anteriores lo encontramos en la sentencia definitiva dictada en autos sobre tutela T-22-2010 por el Juez del Trabajo de Temuco. En dicha sentencia, fallando sobre la procedencia de indemnización por lucro cesante de los demandantes, y a fin de determinar los montos condenatorios exactos, el tribunal determina en su considerando vigésimo:

"[...] La indemnización del lucro cesante aparece aquí como una medida reparadora adecuada, ya que de no haber mediado el cese anticipado e injustificado de las contratas de los actores, ellos tenían una expectativa razonable de haber obtenido el pago de sus remuneraciones hasta el 31 de diciembre de 2010, cuando la autoridad podía ponerle término. Justo es que, al menos, los demandantes perciban los sueldos que le hubieren correspondido hasta esa fecha, conforme lo faculta el artículo $495 \mathrm{~N}^{\circ} 3$ del Código del Trabajo.

Para tales fines los actores señalaron en su demanda percibir una suma distinta a la que indican las liquidaciones del mes de mayo incorporadas por los propios demandantes, en las que se observa un sueldo de \$330.772 para don Luis Alvial Fernández, de \$333.184 para don Ricardo Wegner Barrientos y de \$288.711 para don Cristian Castillo. Sin embargo, en todas se señala que la "modernización correspondiente al mes de mayo de 2010 se cancela con un cheque", con lo que se da a entender que su remuneración es diferente.

Consagrando el artículo 444 del Código del Trabajo el principio cautelar que permite al juez realizar todas las medidas que se estimen necesarias para asegurar el resultado de la acción, para solucionar esta dicotomía se ha recurrido a la página web oficial del Gobierno www.gobiernotransparentechile.cl en la que se publica toda la información oficial para los fines de la ley 20.285. En dicha página se informa que un profesional grado 8 que presta servicios en la Intendencia de la Araucanía percibe $\$ 1.594 .765$, un profesional grado $10 \$ 1.344 .311$ y uno grado 12 $\$ 1.135 .672$, por lo que se estará a tales sumas para fijar el monto de la indemnización por lucro cesante".

De lo expuesto se deduce que el magistrado ha estimado pertinente para asegurar el fin de la acción utilizar la potestad cautelar consagrada en el artículo 444 del Código del Trabajo, recurriendo a la página web que ha estimado idónea para la obtención de la información. Sin embargo, ¿es un ejercicio de la potestad cautelar el que está realizando el juez en este caso, 
o más bien está en el límite de la intervención probatoria activista? Creemos que el punto discutido (la "dicotomía", en palabras del magistrado) puede ser, por su relevancia, parte constitutiva del thema decidendi; parte de los hechos controvertidos que habría de probar en juicio. Dejamos abierta la observación, pero consta aquí una vez más la variedad de hipótesis conflictivas que trae aparejada la comprensión del artículo 444 como una norma potestativa abierta.

Sin duda la recolección de antecedentes jurisprudenciales por ahora seguirá siendo una tarea por realizar, y que de seguro dará origen a una investigación independiente muchísimo más acabada, pero por ahora he de limitarme a lo expuesto en las páginas precedentes y a exponer de manera ejemplar un par de situaciones que pueden acercar la discusión a la práctica. Es de esperar que las posibilidades que se abren a una interpretación laxa de las potestades judiciales en materia cautelar no sean ampliamente utilizadas por nuestros tribunales, y precisamente aquello dificulte nuestra tarea de investigación jurisprudencial crítica futura. De ser así, aquello será índice, en mayor o menor medida, de que lo que aquí hemos tratado no ha podido ser más acertado, y que el buen juicio gobierna aún las mentes de la magistratura laboral. De lo contrario, de encontrar en este espacio una veta para la experimentación innovativa o anticipatoria, no dudaremos en volver sobre el tema.

\section{Conclusiones}

En nuestro ordenamiento jurídico nacional se ha seguido la tradición moderna de sujetar los poderes del Estado a la ley, y hoy más ampliamente, al Principio de Juridicidad. Si bien este principio consagrado constitucionalmente no se limita a la tradicional legalidad en su vertiente de vinculación positiva, sí es posible afirmar que contiene esta dimensión en su dinámica de superación. En otras palabras, no supera a la tradicional legalidad porque se crea una lectura nueva de ésta, sino porque la incluye y trasciende (abarcando sujeción a los derechos fundamentales, por ejemplo).

Dicha concepción es plenamente coherente con la consagración constitucional de la primacía de la persona humana, y desde esa misma lectura, esta posición se condice a la vez con una lectura garantista del proceso, siendo esta corriente la que mejor se condice con nuestra Norma Fundamental, y con los diversos tratados internacionales que consagran garantías de orden procesal.

Luego, la vinculación de los poderes del Estado (o de las funciones, siendo más preciso) al principio de juridicidad tiene un alcance particular tratándose de los tribunales de justicia, quienes ejercen la función jurisdiccional. Respecto de aquellos será principalmente la ley procesal la que consagre típicamente la 
atribución potestativa que permite el desarrollo dialéctico del Proceso conforme a las prerrogativas constitucionales mínimas.

En este sentido, la consagración de potestades abiertas o atípicas no es coherente con el propio contenido constitucional, y llega a vulnerar incluso, dependiendo de lo laxo de su lectura, a la noción de Proceso, desnaturalizando el ejercicio de la función ejercida por el Estado ante el requerimiento de particulares para la solución de conflictos intersubjetivos.

No es concebible entonces que pueda desprenderse de la norma procesal laboral estudiada una potestad cautelar genérica, e indeterminada. En primer lugar porque la Constitución ha encomendado al Legislativo (órgano democráticamente idóneo) la consagración expresa de las potestades públicas, y al hacer aquello se pretende trasladar una función nomogenética impropia al juez laboral, atentando contra los principios fundamentales de legalidad, juridicidad, certeza jurídica y seguridad jurídica, y en el fondo, con el derecho a defensa de las partes en juicio.

En segundo lugar, no puede tampoco obviarse la observación planteada justificando la lectura abierta potestativa en el desequilibrio constituyente de la relación laboral, pues si bien es de nuestro parecer que dicha desigualdad ha de ser equiparada materialmente, no podemos entregar al juez la solución procurando que intervenga lo más posible. Aquello implica atribuirle una función impropia, pues precisamente el ejercicio de la función jurisdiccional presupone esencialmente imparcialidad e impartialidad por parte del juzgador, y con encomendarle la misión prescrita desnaturalizamos el proceso, transformándolo en mero procedimiento. La equiparación en la relación laboral ha de buscarse en la nomogénesis propia del Legislativo conforme al orden democrático establecido. No es recomendable bajo ningún aspecto iniciar el sacrificio del único agente estatal cuyo compromiso fundamental es ser imparcial, que no ha de tener interés en la solución del juicio ni debe actuar como parte en el mismo: el juez.

En este camino, la interpretación de normas potestativas como aquella sobre la que hemos tratado en las líneas precedentes a propósito de la función cautelar, ha de ser coherente con la propia estructura institucional que se ha elevado como legítima y vigente en el contexto democrático actual. Una vez más es posible afirmar que sin duda las intenciones últimas que han de fundar materialmente los textos normativos vigentes puedan ser loables y estar inspiradas en un "espíritu de justicia". Sin embargo, las intenciones no son más que eso; meras intenciones. La realidad efectiva del Derecho y la práctica judicial misma serán el lugar en dónde se decidirá en último término lo adecuado o inadecuado de lo propuesto. 


\section{BibliOgRAFÍA CITADA}

Academia Judicial (2008): Manual de juicio del trabajo. (Santiago, Chile, Academia Judicial).

Aldunate LizANA, Eduardo (1995): "La independencia judicial: aproximación teórica, consagración constitucional y crítica", en: Revista de Derecho de la Universidad Católica de Valparaíso ( $\left.\mathrm{N}^{\circ} \mathrm{XVI}\right)$, pp. 11-26.

Alvarado Velloso, Adolfo (2011): Lecciones de Derecho Procesal Civil. Botto OAKLEY, Hugo (Adaptador) (Santiago, Punto Lex, Thomson Reuters).

Alvarado Velloso, Adolfo (2008): Cautela Procesal (crítica a las medidas precautorias) (Rosario, Argentina, Editorial luris).

Bermúdez Soto, Jorge (2008): "El principio de legalidad y la nulidad de Derecho Público en la Constitución Política. Fundamentos para la aplicación de una solución de Derecho Común". En: Revista de Derecho Público (Vol. 70), Universidad de Chile, pp. 273-287.

BisoGNO, Julieta (2003): “ $i$ Las medidas autosatisfactivas cumplen con la garantía constitucional de la defensa en juicio?", en: Revista Jurídica Cajamarca (Número 12, Julio Septiembre), Disponible en: http://www.derechoycambiosocial.com/RJC/Revista12/medidas.htm [visitado 05/03/2015].

Bontes Calderón, Irma y Mirabal Rendón, Iván. "El rol del Juez en el Proceso laboral", ponencia presentada en $X X^{\circ}$ Congreso mundial: Santiago (Chile), 25-28 de septiembre de 2012, Disponible en:http://islssl.org/wp-content/ uploads/2013/03/Venezuela-CalderonRendon.pdf [visitado el 02/03/2015].

Bordalí Salamanca, Andrés (2001): "Diversos significados de la tutela cautelar en el proceso civil". En: Revista de Derecho Valdivia (Vol. 12, № 2), pp. 51-66.

Calamandrel, Piero (1945): Introducción al estudio sistemático de las providencias cautelares (trad. de Sentís Melendo. Buenos Aires, EJEA).

Caldera Delgado, Hugo (2001): Tratado de Derecho Administrativo. (Santiago, Ediciones Parlamento), Tomo I.

Caldera Delgado, Hugo (1982): Sistema de la responsabilidad extracontractual del Estado en la Constitución Política de 1980 (Santiago, Chile, Editorial Jurídica de Chile).

Carretta Muñoz, Francesco (2014): "La desformalización del proceso judicial de familia e infancia", en: Revista de Derecho Valparaíso (№ 42), pp. 481-495.

Cea Egaña, José Luis (2008): Derecho Constitucional Chileno. $2^{\text {a }}$ edición (Santiago, Eds. Universidad Católica de Chile, Vicerrectoría de Comunicaciones y Asuntos Públicos).

CIPRIANI, Franco (2007): "El procedimiento cautelar, entre eficiencia y garantías", en: Proceso civil hacia una nueva justicia civil/ Andrés de la Oliva Santos et al.; coordinación Andrés de la Oliva Santos, Diego Iván Palomo Vélez. (Santiago, Chile, Ed. Jurídica de Chile). 
Fiamma Olivares, Gustavo (1991): "Acción constitucional de nulidad y legitimación activa objetiva". En: Revista de Derecho Público (№ 49), pp. 91-98.

Garcia, José Francisco y Verdugo, Sergio (2013): Activismo Judicial en Chile. ¿Hacia el gobierno de los jueces? (Santiago, Chile, Ediciones L Y D).

Hunter Ampuero, Iván. (2011): "Rol y poderes del juez civil: una mirada desde la eficiencia del proceso", en: Revista de Derecho, pp. 73-101.

Hunter Ampuero, Iván (2007): "Poderes del juez civil. Algunas consideraciones a propósito del juez de familia", en: Revista de Derecho (Valdivia) (20, 1), pp. 205-229.

LANATA FuenZALIDA, Gabriela (2010): Manual de proceso laboral (Santiago, Editorial Abeledo Perrot).

MARíN, Juan Carlos (2006): "Las medidas cautelares en el ordenamiento jurídico chileno: su tratamiento en algunas leyes especiales", en: Revista de Estudios de la Justicia ( $\left.\mathrm{N}^{\circ} 8\right)$, pp. 13-37.

Morales, Evelyn (2008): "Las medidas cautelares innominadas en el Proceso Civil Venezolano", en: Revista de la Facultad de Ciencias Jurídicas y Políticas, pp. 503-525.

Ortiz Ortiz, Rafael (s/f): "Las medidas innominadas en el procedimiento civil venezolano", en: Revista de la Facultad de Ciencias Jurídicas y Políticas de la Universidad Central de Venezuela, Caracas (Año XXXX, № 94), pp. 27-28.

Ovalle Favela, José. (1998): "Tutela Anticipada en el proceso civil iberoamericano", en: Revista del Instituto de la judicatura federal (No 3), pp. 269-304.

PAlAVECINO CÁCERES, Claudio (2012): "La reforma procesal laboral chilena. Una visión crítica desde el garantismo procesal", en: Revista Laboral Chilena ( No 208), pp. 59-68.

PalaveCino Cáceres, Claudio y Ramírez, Cristián (2010): "Examen crítico de la sentencia anticipada en el procedimiento monitorio laboral". En: Revista Chilena de Derecho del Trabajo y de la Seguridad Social, Facultad de Derecho de la Universidad de Chile (Volumen 1, № 2), pp. 71-80.

Palomo Vélez, Diego y Matamala Souper, Pedro (2012): "Prueba, inmediación y potestades en el proceso laboral: observaciones críticas y apelación al equilibrio", en: RDUCN (Vol. 19, No 2), pp. 237-274.

Peyrano, Jorge W. "Las Medidas Anticautelares". Disponible en: $<$ http://elateneo.org/documents/trabajosBajar/LASMEDIDASANTICAUTELARES.pdf> [visitado el 10/02/2015].

Plascencia Cruz, Jorge Antonio (2008): "La buena fe en el proceso cautelar", en: Jus doctrina \& práctica - № 2 (feb. 2008), Lima, Perú. Disponible en: http:// www.derechoycambiosocial.com/revista013/buena\%20fe $\% 20$ en $\% 20 \mathrm{el} \% 20$ proceso \%20cautelar.htm [visitado el 05/03/2015]. 
Rengel Romberg, Arístides (1989): "Medidas Cautelares Innominadas", en: Revista del Instituto Colombiano de Derecho procesal (Vol. 8).

Rey Cantor, Ernesto y Rey Anaya, Ángela Margarita (1996): Medidas provisionales y medidas cautelares en el sistema interamericano de derechos humanos. (México, Instituto Interamericano de Derechos Humanos).

Reyes Riveros, Jorge (2000): "Los principios aplicables respecto del papel instrumental del Estado frente a los derechos y deberes de las personas", en: Revista de Derecho Público Universidad de Chile (Vol. 62), pp. 147-164.

ReYes Riveros, Jorge (1998): "El principio de juridicidad y la modernidad", en: Revista Chilena de Derecho (Vol. 25, № 1), pp. 85-102.

RuAY SÁEZ, Francisco Alberto (2013): "Análisis crítico sobre la inclusión del principio de buena fe procesal en el Proyecto de Código Procesal Civil chileno", en: Revista de Derecho y Ciencia Política (Vol. 4, 2013), pp. 53-82.

Sото KLoss, Eduardo (1996): Derecho Administrativo: Bases fundamentales. (Santiago de Chile, Editorial Jurídica de Chile), Tomo II.

Sото KıOss, Eduardo (1997): "La nulidad de derecho público: su actualidad", en: Revista de Derecho de la Pontificia Universidad Católica de Valparaíso (No 18), pp. 347-355. 